\title{
INFLUENCE OF AGE ON THE CELL BIOLOGICAL CHARACTERISTICS AND THE STIMULATION POTENTIAL OF MALE HUMAN TENOCYTE-LIKE CELLS
}

\author{
F. Klatte-Schulz ${ }^{1,2}$, S. Pauly ${ }^{1 \#}$, M. Scheibel ${ }^{1}$, S. Greiner ${ }^{1}$, C. Gerhardt ${ }^{1}$, G. Schmidmaier ${ }^{3}$ and B. Wildemann ${ }^{1,2, *}$ \\ ${ }^{1}$ Julius Wolff Institute, Center for Musculoskeletal Surgery, Charité-Universitaetsmedizin, Berlin, Germany \\ ${ }^{2}$ Berlin-Brandenburg Center for Regenerative Therapies, Charité-Universitaetsmedizin, Berlin, Germany \\ ${ }^{3}$ Department Orthopädie, Unfallchirurgie und Paraplegiologie, Universitätsklinikum Heidelberg, Heidelberg, Germany
}

\# F. Klatte-Schulz and S. Pauly contributed equally to this manuscript

\begin{abstract}
The incidence of rotator cuff tears and recurrent defects positively correlate with patient age. However, this observation has never been analysed at the cellular level. The present study aims to better understand this correlation by investigating cellular characteristics of rotator cuff tenocytes of different age groups. Additionally, previous studies reported on stimulating effects of Bone Morphogenetic Protein (BMP) -2 and BMP-7 on tenocytes. Thus, the second aim was to investigate, whether the stimulation potential of tenocytes demonstrates age-related differences.

Tenocyte-like cells from supraspinatus tendons of young and aged male patients were analysed for the following cell biological characteristics: cell density, cell growth, marker expression, collagen-I protein synthesis, stem cell phenotype, potential for multipotent differentiation and self-renewal. To analyse the stimulation potential, cells were treated with BMP-2 and BMP-7 in 2D-/3D-cultures. Measured parameters included cell activity, marker expression and collagen-I protein synthesis.

An effect of age was seen for cell growth and stem cell potential but not on extracellular matrix level. Cells from both groups responded to BMP-7 by increasing cell activity, collagen-I expression and protein synthesis. BMP-2 led to smaller increases in these parameters when compared to BMP-7. In general, 3D-cultivation improved the stimulation compared to 2D-culture.

The cell biological characteristics of tenocyte-like cells, considered important for successful restoration of the tendon-bone unit, were inferior in elderly donors. This may help explain higher rates of recurrent defects seen in elderly patients. Regarding the stimulation potential, on a cellular level young and aged patients may benefit from biological augmentation with BMPs.
\end{abstract}

Keywords: Tenocyte-like cells, age; rotator cuff; BMP-2; BMP-7; 2D-culture; 3D-culture.

* Address for correspondence:

Britt Wildemann

Julius Wolff Institute

Berlin-Brandenburg Center for Regenerative Therapies

Center for Musculoskeletal Surgery

Charité-Universitaetsmedizin Berlin

Augustenburger Platz 1, D-13353 Berlin, Germany

Telephone Number: +49-30 -450559618

FAX Number: +49-30 -450559938

E-mail: Britt.Wildemann@charite.de

\section{Introduction}

Tears of the rotator cuff, and in particular the supraspinatus (SSP) tendon, are highly prevalent orthopaedic morbidities in the adult populations. Patients frequently suffer from pain and disability and in many cases require surgical reconstruction. However, despite biomechanical improvements in reconstruction techniques (Pauly et al., 2010a; Pauly et al., 2011a), clinical and radiographic mid-term results are often unsatisfactory (Burks et al., 2009; Grasso et al., 2009; Aydin et al., 2010), and may indicate insufficient regeneration of the tendon-bone interface at the humeral insertion. In animal studies it was demonstrated that the complex process of tendon-bone healing results in the formation of a biomechanically inferior scar tissue, rather than the regeneration of the native tendon-bone tissue (Gerber et al., 1999; Rodeo, 2007). Accordingly, non-healing and recurrent defects are the most frequent complications following surgical reconstructions (Boileau et al., 2005; Deutsch et al., 2008; Frank et al., 2008; Burks et al., 2009).

Several clinical and radiographic follow-up studies of large patient cohorts have investigated factors associated with these postoperative complications. These included demographic factors, such as patient age (Milgrom et al., 1995; Boileau et al., 2005; Yamaguchi et al., 2006; Sorensen et al., 2007) and gender (Grasso et al.., 2009; Chung et al., 2011;), as well as radiographic characteristics, such as fatty infiltration of the respective muscle (Goutallier et al., 2003; Gladstone et al., 2007; Shen et al., 2008; Cho et al., 2011). However, as these were epidemiological studies, they do not provide causal or biological explanations for the reason of impaired healing. It is possible that cellular or even molecular characteristics could give rise to these correlations. These include for example weaker tenocyte cell growth or cell activity, lower cell density in the tendon, lower stem cell potential of the tenocytes or a decreased synthesis of extracellular matrix (ECM) proteins like collagen-I (Col-I).

In order to improve the quality of tendon tissue after surgical reconstruction, biologically based strategies have gained increasing interest over the last several years. Important to these strategies is the regenerative capacity of the tenocytes (e.g. cell activity, proliferation, ECM synthesis), and it has been suggested that the exogenous application of growth factors could improve tendon healing (Maffulli et al.., 2002; Hsu and Chang, 2004). Several experimental approaches in vivo (Rodeo et al., 1999; Martinek et al., 2002; Mihelic et al., 2004; Ma et al., 
Table 1. Real-Time PCR primers.

\begin{tabular}{|c|c|c|c|}
\hline $\begin{array}{l}\text { Target gene } \\
\text { (Accession number) }\end{array}$ & $\begin{array}{l}\text { Product size } \\
\text { [bp] }\end{array}$ & $\begin{array}{l}\text { Annealing } \\
\text { temperature }\left[{ }^{\circ} \mathrm{C}\right]\end{array}$ & Sequence $\left[5^{\prime}-3^{\prime}\right]$ \\
\hline GAPDH (NM_002046) & 115 & $64.2 ; 66.0$ & $\begin{array}{l}\text { Forward: CCACTCCTCCACCTTTGACG } \\
\text { Reverse: CATGAGGTCCACCACCCTGT }\end{array}$ \\
\hline Col-I (NM_000088) & 197 & 64.2 & $\begin{array}{l}\text { Forward: TGACCTCAAGATGTGCCACT } \\
\text { Reverse: ACCAGACATGCCTCTTGTCC }\end{array}$ \\
\hline Col-II (NM_001844) & 162 & 66.0 & $\begin{array}{l}\text { Forward: CGCACCTGCAGAGACCTGAA } \\
\text { Reverse: TCTTCTTGGGAACGTTTGCTGG }\end{array}$ \\
\hline Col-III (NM_000090) & 199 & 64.2 & $\begin{array}{l}\text { Forward: GCTGGCATCAAAGGACATCG } \\
\text { Reverse: TGTTACCTCGAGGCCCTGGT }\end{array}$ \\
\hline $\begin{array}{l}\text { Osteocalcin } \\
\text { (NM_199173) }\end{array}$ & 209 & 64.2 & $\begin{array}{l}\text { Forward: CCCAGGCGCTACCTGTATCAA } \\
\text { Reverse: CTGGAGAGGAGCAGAACTGG }\end{array}$ \\
\hline Decorin (NM_001920) & 205 & 64.2 & $\begin{array}{l}\text { Forward: CGCCTCATCTGAGGGAGCTT } \\
\text { Reverse: TACTGGACCGGGTTGCTGAA }\end{array}$ \\
\hline TGF- $\beta 1$ (NM_000660) & 116 & 64.2 & $\begin{array}{l}\text { Forward: AAGGACCTCGGCTGGAAGTG } \\
\text { Reverse: AGGGCCAGGACCTTGCTGTA }\end{array}$ \\
\hline $\begin{array}{l}\text { TGF- } \beta 2 \\
\text { (NM_001135599) }\end{array}$ & 185 & 64.2 & $\begin{array}{l}\text { Forward: CAACAGCACCAGGGACTTGC } \\
\text { Reverse: AGCACAAGCTGCCCACTGAG }\end{array}$ \\
\hline TGF-ß3 (NM_003239) & 136 & 64.2 & $\begin{array}{l}\text { Forward: CTGCTGGAGGAGATGCATGG } \\
\text { Reverse: GGCAGACAGCCAGTTCGTTG }\end{array}$ \\
\hline
\end{tabular}

2007; Rodeo et al., 2007), and in vitro (Salingcarnboriboon et al., 2003; Tsai et al., 2003; Thomopoulos et al., 2005; Yamada et al., 2008; Yeh et al., 2008, Pauly et al., 2011b) have demonstrated that Bone Morphogenetic Protein (BMP)-2 and -7 can stimulate tendon cells, and assist in the restoration of a solid tendon-bone complex. However, possible age-related differences in tissue susceptibility to growth factor exposure are unknown. Aged patients, who possibly have a reduced cell biological potential, may particularly benefit from growth factor augmentation during rotator cuff repair.

The primary aim of the present study was to analyse cell biological characteristics of tenocyte-like cells from male human donors in order to investigate possible reasons for increased incidence of recurrent defects with age. The second focus was to investigate, whether there are age-related differences in the stimulation potential of tenocyte-like cells treated with BMP-2 or BMP-7.

\section{Materials and Methods}

Tendon material, donor demographics, clinical data SSP tendon samples were obtained from patients undergoing arthroscopic surgery for rotator cuff repair or open shoulder surgery, such as hemiarthroplasty after humeral head fractures. All biopsies were obtained according to a standardised protocol and were grasped 3 to $5 \mathrm{~mm}$ from the torn proximal tendon edge. Prior to biopsy, all patients gave their written informed consent.

Studies suggested that beyond the age of 60 to 65 years, the incidence of recurrent defects strongly increased (Milgrom et al., 1995; Gerber et al., 1999; Boileau et al., 2005; Tashjian et al., 2010). Accordingly, the age cut-off was defined at 65 years. All donors younger than 65 years were categorised "young" and 65 years or more "aged" in the current study.

In this study, the male donors differed with regard to age. Young donors had a mean age of 45.3 years (range:
42-50 years) and aged donors of 71.3 years (range: $66-75$ years). Among all included donor patients, fatty infiltration of the SSP muscle was graded 0-I according to Goutallier (Goutallier et al., 1994) on MRI scans (Fuchs et al., 1999). Tendon retraction was graded 0-2 according to Patte (Patte, 1990) and tear size staged I-III according to Bateman (Bayne, 1984), depending on preoperative MRI assessment and intraoperative diagnostics. The radiological characteristics were evenly distributed between the two groups.

\section{Cell density}

Tenocyte-like cells were isolated from the SSP tendon biopsies as described previously (Pauly et al., 2011b). Prior to digestion with $0.3 \%$ collagenase type CLS II, the SSP biopsies were weighted under sterile conditions. Digested tendon material was then plated onto a culture flask with a ratio of tendon material $(\mathrm{mg}) /$ growth area $\left(\mathrm{cm}^{2}\right)$ from 0.2 to 0.3 in order to allow all cells to grow under similar culture conditions. The cells were cultured with normal growth medium (DMEM/Ham's F12 with $10 \%$ foetal calf serum (FCS) and $1 \%$ penicillin/streptomycin, all Biochrom, Berlin, Germany) at $37^{\circ} \mathrm{C}$, with $95 \%$ humidity and $5 \%$ carbon dioxide, with a change of medium every 2 to $3 \mathrm{~d}$. After one week of culture, cell activity was analysed with an Alamar Blue assay (Biochrom) according to the manufacturer's instructions. The cell count in the culture flask was calculated by a standard curve (defined cell number). To calculate the approximate cell density, the cell count was normalised to the weight of the tendon biopsy.

\section{Cell growth}

The tenocyte-like cells in passage 2 were seeded with $2.5 \times 10^{3}$ vital cells per well in a 48 -well plate, and in triplicates. At day 1, 4, 7 and 14 after seeding, an Alamar Blue assay was performed to analyse cell activity. Between day 7 and day 14 of culture two times a half change of medium was performed. The cell count was calculated with a standard curve, and the cell count of day 4, 7 and 14 was 
Table 2. Antibodies used for FACS analysis

\begin{tabular}{|l|l|l|l|l|}
\hline Name & Label & Clone & Company & Dilution \\
\hline CD29 & Phycoerythrin (PE) & T52/16 & Biolegend, Uithoorn, Netherlands & $1: 100$ \\
\hline CD44 & PE-Cy7 & IM7 & Biolegend & $1: 1000$ \\
\hline CD73 & Allophycocyanin (APC) & AD2 & Biolegend & $1: 400$ \\
\hline CD90 & Peridinin Chlorophyll Protein (PerCP)-Cy5.5 & 5 E10 & Biolegend & $1: 400$ \\
\hline CD105 & Fluorescein Isothiocyanat (FITC) & 43A3 & Biolegend & $1: 100$ \\
\hline CD11b & Pacific blue & ICRF44 & BD Biosciences & $1: 1000$ \\
\hline CD14 & Pacific blue & MOP9 & BD Biosciences & $1: 1000$ \\
\hline CD19 & Pacific blue & HIB19 & BD Biosciences & $1: 1000$ \\
\hline CD34 & Pacific blue & 581 & Biolegend & $1: 1000$ \\
\hline CD45 & Pacific blue & HI30 & BD Biosciences & $1: 1000$ \\
\hline Life/Dead & Aqua Fluorescent reactive dye & & Invitrogen, Darmstadt, Germany & $1: 1000$ \\
\hline
\end{tabular}

referred to cell count of day 1 by subtraction to assess the cell growth of the tenocyte-like cells over time.

\section{Marker expression}

Methods for cell characterisation were based on results from a previous study (Pauly et al., 2010b), and included analysis of Col-I, -II, -III, and osteocalcin expression. Additionally, expression of decorin, transforming growth factor (TGF)- $\beta 1,-\beta 2$, and $-\beta 3$ was analysed. RNA was isolated from the tenocyte-like cells at passage 2 with the NucleoSpin RNA II Kit (Machary Nagel, Dueren, Germany) according to the manufacturer's instructions. RNA concentrations were measured with the Nanodrop ND-1000 Spectrophotometer (PeqLab Biotechnologie, Erlangen, Germany). Subsequently, $100 \mathrm{ng}$ of RNA was transcribed into cDNA with the qScript cDNA Supermix (Quanta BioSciences, Gaithersburg, MD, USA) following the manufacturer's instructions. An Epgradient Mastercycler (Eppendorf, Hamburg, Germany) was used for cDNA synthesis.

All primer sequences were designed using Primer 3 software (Freeware; http://frodo.wi.mit.edu/primer3), and were produced by Tib Molbiol, Berlin, Germany (Table 1). The Real-Time PCR was performed with the Realplex Mastercycler System (Eppendorf). The cDNA was diluted 1:20 and $5 \mu \mathrm{L}$ was pipetted into each well as PCR template. The mastermix was prepared with the following components for each well: $12.5 \mu \mathrm{L}$ Sybr Green Supermix (Quanta BioSciences), $1 \mu \mathrm{L}$ primermix $(10 \mu \mathrm{M}$, forward and reverse Primer 1:1), and 6.5 $\mu \mathrm{L}$ RNase/DNase-free water. $20 \mu \mathrm{L}$ of the mastermix was added to each well. The following Real-Time PCR protocol was used for the amplification: a denaturation program $\left(95^{\circ} \mathrm{C}\right.$ for $\left.3 \mathrm{~min}\right)$, an amplification program repeated for 40 cycles $\left(95^{\circ} \mathrm{C}\right.$ for $15 \mathrm{~s}, 64.2^{\circ} \mathrm{C} / 66^{\circ} \mathrm{C}$ for $45 \mathrm{~s}, 72{ }^{\circ} \mathrm{C}$ for $30 \mathrm{~s}$ ), a melting curve program $\left(55-95{ }^{\circ} \mathrm{C}\right.$ with a temperature change of $0.5{ }^{\circ} \mathrm{C}$ holding for $30 \mathrm{~s}$ ), and finally a cooling step at $15^{\circ} \mathrm{C}$. The Real-Time PCR results were analysed with the Realplex Software (Eppendorf). Relative expression levels were normalised to GAPDH, and calculated using the $2^{-\Delta \mathrm{Ct}}$ method.

\section{Col-I protein synthesis}

Levels of Col-I protein were measured from the cell culture supernatant taken at day 4, 7 and 14 of cell growth analysis by using MicroVue C1CP EIA Kit (TecoMedical, Buende,
Germany) according to manufacturer's instructions. Levels were normalised to total protein content of the supernatant (Coomassie Plus ${ }^{\mathrm{TM}}$ Protein Assay, Thermo Fisher Scientific, Bonn, Germany).

\section{Stem cell phenotype}

For analysing the stem cell phenotype, fluorescent activated cell sorting (FACS) was performed. Confluent cells from a $75 \mathrm{~cm}^{2}$ bottle (about 2.5-5 x 105 vital cells) were harvested in passage 1. An established stem cell panel, including all antibodies, was obtained from the Core Unit of the Berlin-Brandenburg Center for Regenerative Therapies (BCRT). Only the Life/Dead staining was modified, as a different antibody was used. Half of the cells were stained with a Life/Dead reagent, CD29, CD44, CD73, CD90, CD105, and a negative mix consisting of CD11b, CD14, CD19, CD34 and CD45 for $25 \mathrm{~min}$ at $4{ }^{\circ} \mathrm{C}$. All antibodies are listed in Table 2. The other half of the cells served as controls. After staining, the cells were washed with FACS buffer $(0.1 \%$ bovine serum albumin (BSA) in phosphate buffered saline (PBS)), fixed with $1 \%$ paraformaldehyde (PFA), and measured with the BD FACS Canto II System (BD Biosciences, Heidelberg, Germany), and FACS Diva software. The data analysis was performed using the FlowJo 8.8.6 software. All viable cells were analysed for the expression of antigens.

\section{Multipotent differentiation}

The multipotent differentiation of the tenocyte-like cells was tested towards osteogenic, adipogenic, and chondrogenic phenotypes. For osteogenic and adipogenic differentiation, cells at passage 2 were seeded into 24 -well plates $\left(7.5 \times 10^{3}\right.$ vital cells / well $)$, cultured until confluence and then incubated in a modified version of differentiation medium previously described (Pittenger et al., 1999; de Mos et al., 2007). The cells were treated for 3 weeks with osteogenic induction medium $(500 \mu \mathrm{M}$ L-ascorbic acid, $10 \mathrm{mM} \beta$-glycerophosphate and $100 \mathrm{nM}$ dexamathasone in normal growth medium), adipogenic induction medium (1 $\mu \mathrm{M}$ dexamethasone, $1 \mu \mathrm{M}$ insulin, $0.5 \mathrm{mM}$ isobutylmethylxanthine (IBMX) and $60 \mu \mathrm{M}$ indomethacine in normal growth medium), or with normal growth medium (control). Medium was changed twice a week. All cell culture supplements for differentiation medium were obtained from Sigma-Aldrich (Taufkirchen, Germany). 
To quantify the osteogenic differentiation, the tenocyte-like cells were stained with $0.5 \%$ Alizarin Red S (Sigma-Aldrich) in $0.5 \mathrm{M} \mathrm{HCl}$ for $10 \mathrm{~min}$. The staining was solubilised in a solution of $200 \mu \mathrm{L} 5 \%$ SDS (Roth, Karlsruhe, Germany) and $0.5 \mathrm{M} \mathrm{HCl}$ for $5 \mathrm{~min}$, and then measured at $405 \mathrm{~nm}$ against the blank ( $5 \%$ SDS in $0.5 \mathrm{M} \mathrm{HCl}$ ) (Bi et al., 2007). To validate the osteogenic differentiation, cells were stained for Alkaline Phosphatase (ALP) exemplarily. After formalin fixation cells were incubated in ALP staining solution (0.06\% Fast Blue Bb Salt (Waldeck, Muenster, Germany), $0.01 \%$ Naphtol-AS-MX-Phosphate (Sigma-Aldrich), $0.5 \%$ dimethylformamide (Sigma-Aldrich), $2 \mathrm{mM}$ magnesium chloride (Merck, Darmstadt, Germany), and 0.1 M Trisbase (Sigma-Aldrich) in $\mathrm{dH}_{2} \mathrm{O}, \mathrm{pH} 8.5$ ) for $30 \mathrm{~min}$ at $37^{\circ} \mathrm{C}$.

To stain the lipid-vacuoles in the adipogenic differentiated cells, a stain of $0.3 \%$ Oil Red O (SigmaAldrich) in $99 \%$ isopropanol was used for $10 \mathrm{~min}$. After clearing the background with $60 \%$ isopropanol, the staining was solubilised with $250 \mu \mathrm{L} 100 \%$ isopropanol for $10 \mathrm{~min}$, and measured at $490 \mathrm{~nm}$ against the blank (100\% isopropanol) (Bi et al., 2007). The osteogenic and adipogenic differentiation was normalised to the staining of undifferentiated cells.

For chondrogenic differentiation only $n=1$ differentiation was performed for each young and aged donor tenocyte-like cell cultures. $2.5 \times 10^{5}$ vital cells were pelleted into a $15 \mathrm{~mL}$ falcon tube. One tube was incubated with chondrogenic induction medium (100 nM dexamethasone (Sigma-Aldrich), $175 \mathrm{nM}$ L-ascorbic acid (Sigma-Aldrich), $40 \mu \mathrm{g} / \mathrm{mL}$ proline (Sigma-Aldrich), $100 \mu \mathrm{g} / \mathrm{mL}$ pyruvate (Roth), $6.25 \mu \mathrm{g} /$ $\mathrm{mL}$ insulin-transferrin-sodium selenite supplement (ITS, Sigma-Adrich), $1.25 \mathrm{mg} / \mathrm{mL}$ Bovine Serum Albumine (BSA; Sigma-Aldrich), $5.35 \mathrm{mg} / \mathrm{mL}$ linolenacide (SigmaAldrich), $10 \mathrm{ng} / \mathrm{mL}$ TGF- $\beta 1$ (R\&D Systems) in normal growth medium), and one tube with normal growth medium (control), with a change of medium twice a week. After 3 weeks in culture, the cell pellet was fixed with $4 \%$ PFA, and subsequently paraffin embedded. $4 \mu \mathrm{m}$ slices were taken and stained with $1 \%$ Alcian Blue solution (SigmaAldrich) for $30 \mathrm{~min}$. Counterstaining was performed with $0.1 \%$ Kernechtrot (Waldeck Division Chroma, Muenster, Germany) in $5 \%$ aluminium sulphate for $5 \mathrm{~min}$.

\section{Potential for self-renewal}

For testing the potential for self-renewal, a Colony Forming Unit (CFU) assay was performed. 1000 vital cells were seeded into a $10 \mathrm{~cm}$ Petri dish (in triplicates), and cultivated for $11 \mathrm{~d}$ with normal growth medium, with medium change every 2-3 d. For visualisation, the colonies were stained with $1 \%$ methylene blue in borate buffer $/ 1 \%$ azur in $\mathrm{dH}_{2} \mathrm{O}(1: 1$, Sigma-Aldrich) for $10 \mathrm{~min}$. After washing, cells were dried and pictures were taken. An image analysing system with an adaptive threshold was used to quantify the number and size normalised to the number of the CFUs (ImageJ 1.44i, Wayne Rasband, National Institute of Health, Bethesda, MD, USA). All colonies between $1 \mathrm{~mm}^{2}$ and $10 \mathrm{~mm}^{2}$ were counted.

\section{Application of growth factors}

For testing the response of tenocyte-like cells to growth factors, cells were treated with 0 (control), 200, or $1000 \mathrm{ng} /$ mL rhBMP-2 (Wyeth, New York, USA), or rhBMP-7 (R\&D Systems, Wiesbaden, Germany) in both 2D- and 3D-cultures (Optimaix collagen scaffolds, Matricel, Herzogenrath, Germany). The scaffolds consist of highly oriented porcine collagen type I, in which cells can optimally attach, spread and produce extracellular matrix. Cells were seeded into 48 -well plates with about $3 \times 10^{3}$ vital cells / well or about $2 \times 10^{4} /$ scaffold (size $85 \mathrm{~mm}^{3}$ : $6 \mathrm{~mm}$ diameter $\mathrm{x} 3 \mathrm{~mm}$ height) in normal growth medium. For 3D-culture cells were seeded with a drop-on method directly to the scaffolds and cultured in static conditions. After cells reached about $50 \%$ confluence in the 2D-culture (about 4 d) the medium was changed for both culturing conditions to medium without FCS to adjust the cell cycle. The next day (day 0), and at day 3 and 5, an Alamar Blue assay was performed with $500 \mu \mathrm{L} /$ well according to the manufacturer, and then growth factor conditioned medium (200 ng/mL, or $1000 \mathrm{ng} / \mathrm{mL}$ BMP-2, or BMP-7 in DMEM/ HAM's F12 1:1 supplemented with $5 \%$ FCS and 1\% Penicillin/Streptomycin) was applied to the cells. On day 7, a final Alamar Blue assay was performed, and RNA was isolated from the cells in the 2D- and 3D-cultures with the NucleoSpin RNA II Kit (Macherey Nagel, Düren, Germany) according to manufacturer, in order to analyse the gene expression by Real-Time PCR (see marker expression). Relative expression levels were normalised to GAPDH, and to the untreated control, and calculated using the $2^{-\Delta \Delta \mathrm{Ct}}$ method (Livak and Schmittgen, 2001). The Col-I protein synthesis was analysed by ELISA from the cell culture supernatant of day 7 (see Col-I protein synthesis), and normalised to the total protein content (Coomassie Plus ${ }^{\mathrm{TM}}$ Protein Assay).

\section{Visualisation of tenocytes in collagen scaffolds}

After one week of stimulation, collagen scaffolds were fixed with $4 \%$ PFA for $30 \mathrm{~min}$ at $37^{\circ} \mathrm{C}$ and with $25 \mathrm{mM}$ ammonium chloride for $20 \mathrm{~min}$ at $37{ }^{\circ} \mathrm{C}$. Afterwards, scaffolds were embedded in $5 \%$ gelatine $/ 5 \%$ sucrose solution for $2 \mathrm{~h}$ at $37^{\circ} \mathrm{C}$ and then for $4 \mathrm{~h}$ at $4{ }^{\circ} \mathrm{C}$. Scaffolds were cryoembedded with TissueTec (Sakura Finetek, Alphen aan de Rijn, Netherlands) and $25 \mu \mathrm{m}$ cryosections were taken. For the staining, cryosections were fixed with formalin and permeabilised with $0.025 \%$ Triton-X-100 in Tris Buffer Solution (TBS) for $10 \mathrm{~min}$. Afterwards, sections were incubated with Phalloidin Alexa Fluor 488 (Invitrogen, 1:500 in TBS) for $1 \mathrm{~h}$ at room temperature, then washed, incubate with Dapi (Invitrogen, 1:1000 in $\mathrm{dH} 2 \mathrm{O}$ ) for $5 \mathrm{~min}$ and covered with Fluoromount-G (Southern Biotec, Birmingham, AL, USA).

\section{Statistics}

Cells from $n=6$ donors per each group were used for the experiments. All experiments were performed in triplicates. Accordingly, statistics were performed for $n=18$ values for each group. For Real-Time PCR analysis, RNA of triplicates was pooled together $(n=6)$. Statistical analysis 

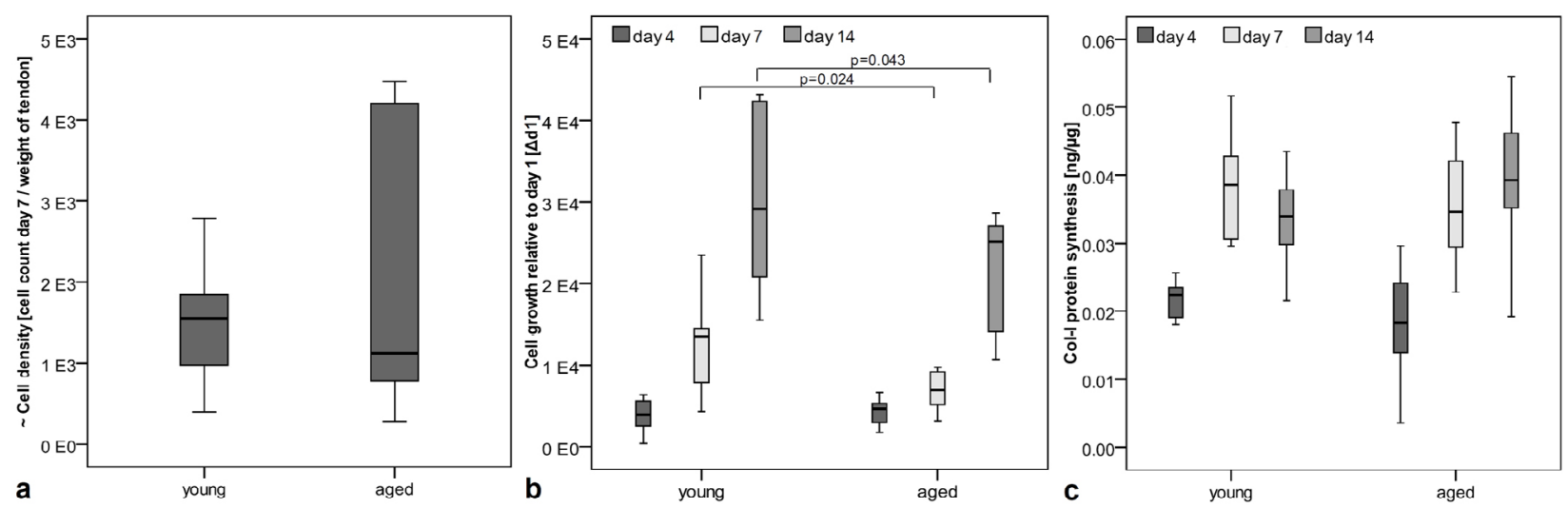

Fig. 1. Comparison of tenocyte-like cells of young and aged donors. (a) Cell density given as cell count of day 7 per weight of tendon biopsy showed no age-related differences. (b) Cell growth measured over 14 days and relative to day 1. Cells of aged donors had significantly decreased cell growth at days 7 and 14. (c) Col-I protein synthesis relative to total protein content was not significantly different between groups at the different time points.

was performed using SPSS 18 (SPSS, Chicago, IL, USA). The Kruskal-Wallis test was used to analyse significant differences between all groups followed by a MannWhitney $\mathrm{U}$ test to compare the young and aged group, or the different concentration groups with the untreated control. All values in the text are given as median with $25-75$ percentiles. The level of significance was set at $p \leq 0.05$ for cell biological characteristics. For the stimulation potential two levels of significance were used, which are 1: $p \leq 0.05$ and 2: $p \leq 0.001$. The Bonferroni-Holm correction was performed to adjust the $\alpha$-value.

\section{Results}

\section{Cell biological characteristics}

The approximate cell density revealed no significant differences between young and aged donors (Fig. 1a). The cell growth was significantly lower in the aged donor group at day 7 and 14 (Fig. 1b). The Col-I protein synthesis increased with time of culture. But in the young donor group a slightly decrease was observed from day 7 to 14 . However, no significant age-related differences between the groups were observed (Fig. 1c).

The characterisation of tenocyte-like cells by RealTime PCR showed that cells of both young and aged donors expressed Col-I and Col-III, weakly expressed Osteocalcin (Table 3), and did not express Col-II (data not shown). The expression of Col-I, Col-III, Osteocalcin, Decorin, TGF- $\beta 1$ and TGF- $\beta 3$ did not show significant differences between the cells of the different donor groups. The mean TGF- $\beta 2$ expression was halved in the tenocyte-like cells of young donors compared to aged donors. However, no significant changes $(p=0.054)$ could be observed (Table 3 ).

The tenocyte-like cells of both donor groups were found to have a stem cell phenotype. They were positive for the CD29, CD44, CD73, CD90 and CD105 antigens but negative for CD11b, CD14, CD19, CD34 and CD45 antigens. With respect to surface markers, no significant differences between cells from young and aged donors were observed (Table 4 and Fig. 2).

The cellular potential for self-renewal (number of colonies and colony size) was significantly higher in cells of young donors (Fig. 3a). $13 \%$ (10-14\%) of tenocyte-like cells of young donors and $7 \%(3-12 \%)$ of cells of aged donors formed adherent cell colonies.

A portion of tenocyte-like cells from both groups had the capacity to differentiate into adipogenic, osteogenic and chondrogenic phenotypes (Fig. 4). Compared to the aged donors, the cells of young donors showed a significantly enhanced osteogenic differentiation potential.

Table 3. Relative gene expression of tenocyte-like cells of young and aged donors.

\begin{tabular}{|c|c|c|c|c|c|c|c|}
\hline & \multicolumn{7}{|c|}{ Relative gene expression normalised to GAPDH $\left[2^{-\mathrm{AC} t}\right]$ given as medians with $25-75$ percentiles } \\
\hline & Col-I & Col-III & Osteocalcin $\left[10^{-4}\right]$ & Decorin & TGF- $\beta 1$ & TGF- $\beta 2\left[10^{-4}\right]$ & TGF- $\beta 3\left[10^{-3}\right]$ \\
\hline Young & $\begin{array}{c}2.70 \\
(2.43-3.20) \\
\end{array}$ & $\begin{array}{c}0.45 \\
(0.37-0.61) \\
\end{array}$ & $\begin{array}{c}8.97 \\
(5.27-12.53) \\
\end{array}$ & $\begin{array}{c}0.14 \\
(0.13-0.30) \\
\end{array}$ & $\begin{array}{c}0.05 \\
(0.04-0.07) \\
\end{array}$ & $\begin{array}{c}1.27 \\
(0.09-2.37) \\
\end{array}$ & $\begin{array}{c}1.42 \\
(1.14-1.99) \\
\end{array}$ \\
\hline Aged & $\begin{array}{c}2.65 \\
(1.98-3.04)\end{array}$ & $\begin{array}{c}0.45 \\
(0.34-0.61)\end{array}$ & $\begin{array}{c}6.65 \\
(4.26-9.47) \\
\end{array}$ & $\begin{array}{c}0.47 \\
(0.13-0.32)\end{array}$ & $\begin{array}{c}0.05 \\
(0.05-0.06)\end{array}$ & $\begin{array}{c}2.70 \\
(2.00-5.00)\end{array}$ & $\begin{array}{c}0.96 \\
(0.65-1.74)\end{array}$ \\
\hline
\end{tabular}

Table 4. Stem cell phenotype of tenocyte-like cells.

\begin{tabular}{|l|c|c|c|c|c|c|}
\cline { 2 - 7 } \multicolumn{1}{c|}{} & \multicolumn{6}{c|}{ Surface marker [\%] given as medians with 25-75 percentiles } \\
\cline { 2 - 7 } \multicolumn{1}{c|}{ CD29+ } & CD44+ & CD73+ & CD90+ & CD105+ & Negative mix+ \\
\hline \multirow{2}{*}{ Young } & 99.96 & 99.99 & 100.00 & 99.95 & 99.13 & 0.19 \\
& $(99.96-99.99)$ & $(99.92-99.99)$ & $(99.99-100.00)$ & $(99.87-99.96)$ & $(97.01-99.60)$ & $(0.03-1.81)$ \\
\hline \multirow{2}{*}{ Aged } & 99.92 & 99.97 & 99.99 & 99.91 & 96.05 & 0.11 \\
& $(99.42-100.00)$ & $(99.90-100.00)$ & $(99.98-100.00)$ & $(99.39-99.97)$ & $(94.47-98.57)$ & $(0.03-0.25)$ \\
\hline
\end{tabular}


CD29PE
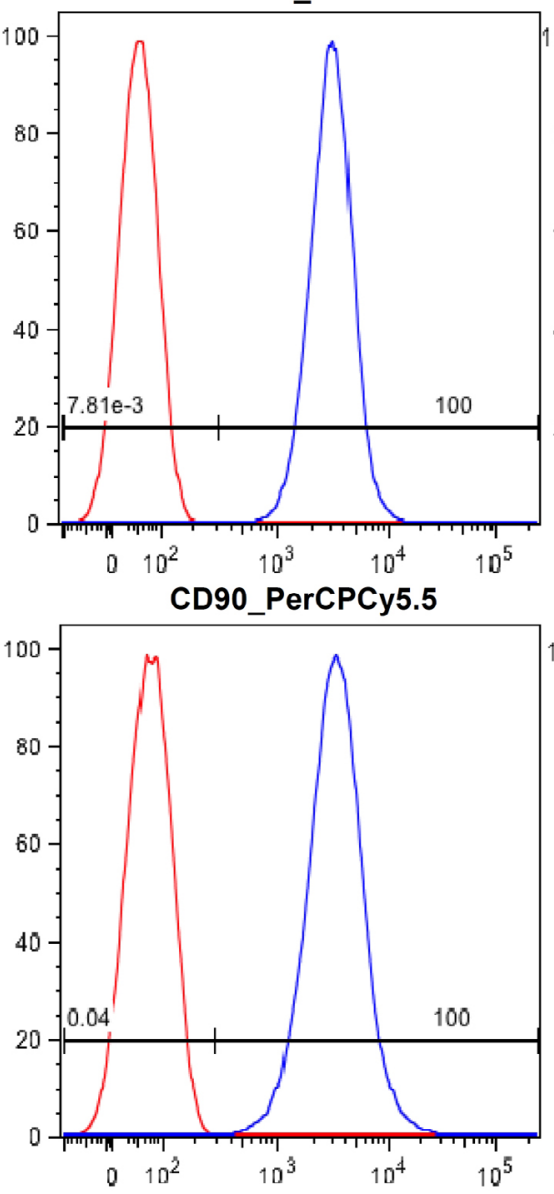

CD44_PECy7
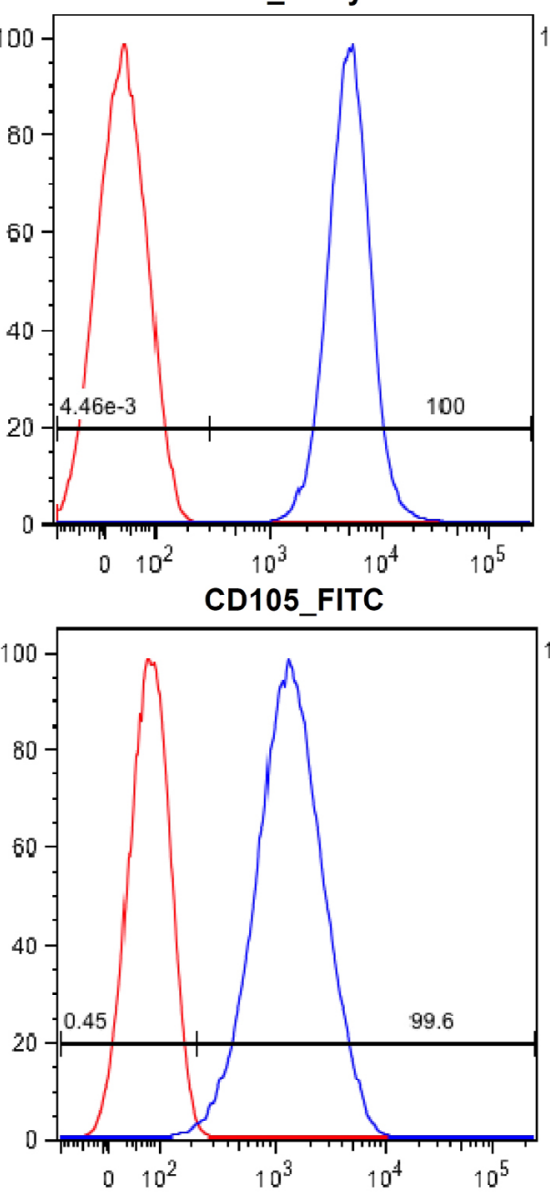

CD73 APC
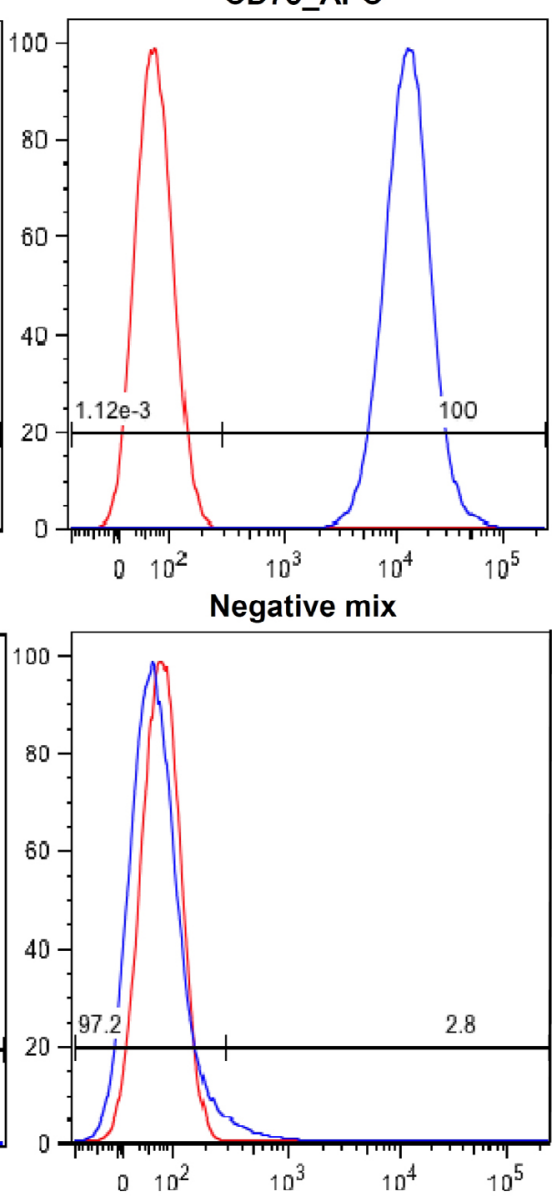

Fig. 2. Exemplary results of FACS analysis of young donor tenocyte-like cells. Graphs show the negative control cells (red curve) compared to stained cells (blue curve). Cells were positive for CD29, CD44, CD73, CD90, CD105 and negative for CD11b, CD14, CD19, CD34, CD45 (Negative mix).
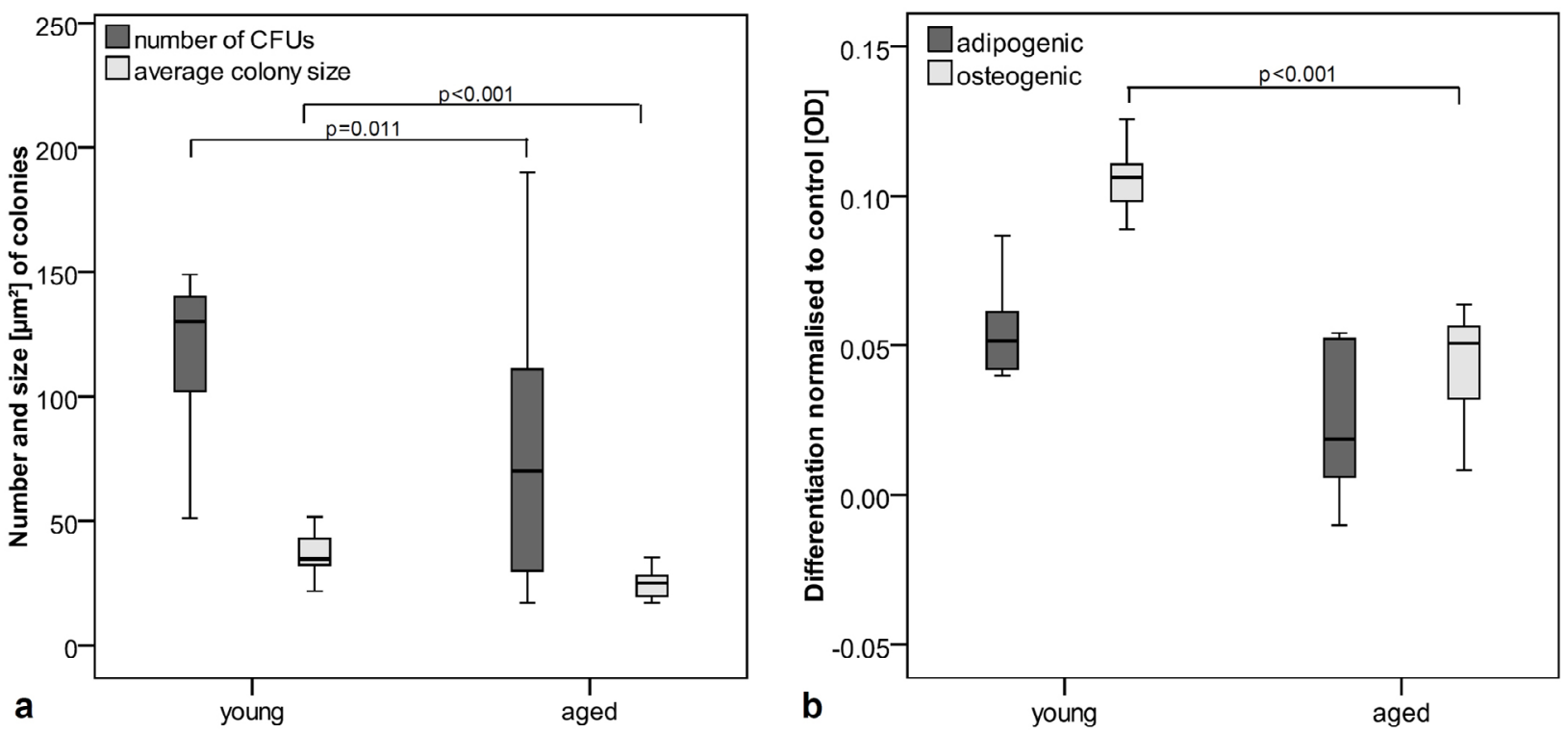

Fig. 3. Comparison of potency for self-renewal and differentiation potential of tenocyte-like cells of young and aged donors. (a) Number of CFUs as well as the average colony size was significantly decreased in the aged donors' cells. (b) Adipogenic and osteogenic differentiation was given as OD normalised to undifferentiated control cells. Adipogenic differentiation was not affected by the age of the donors, but osteogenic differentiation was significantly increased in tenocyte-like cells of young donors. 

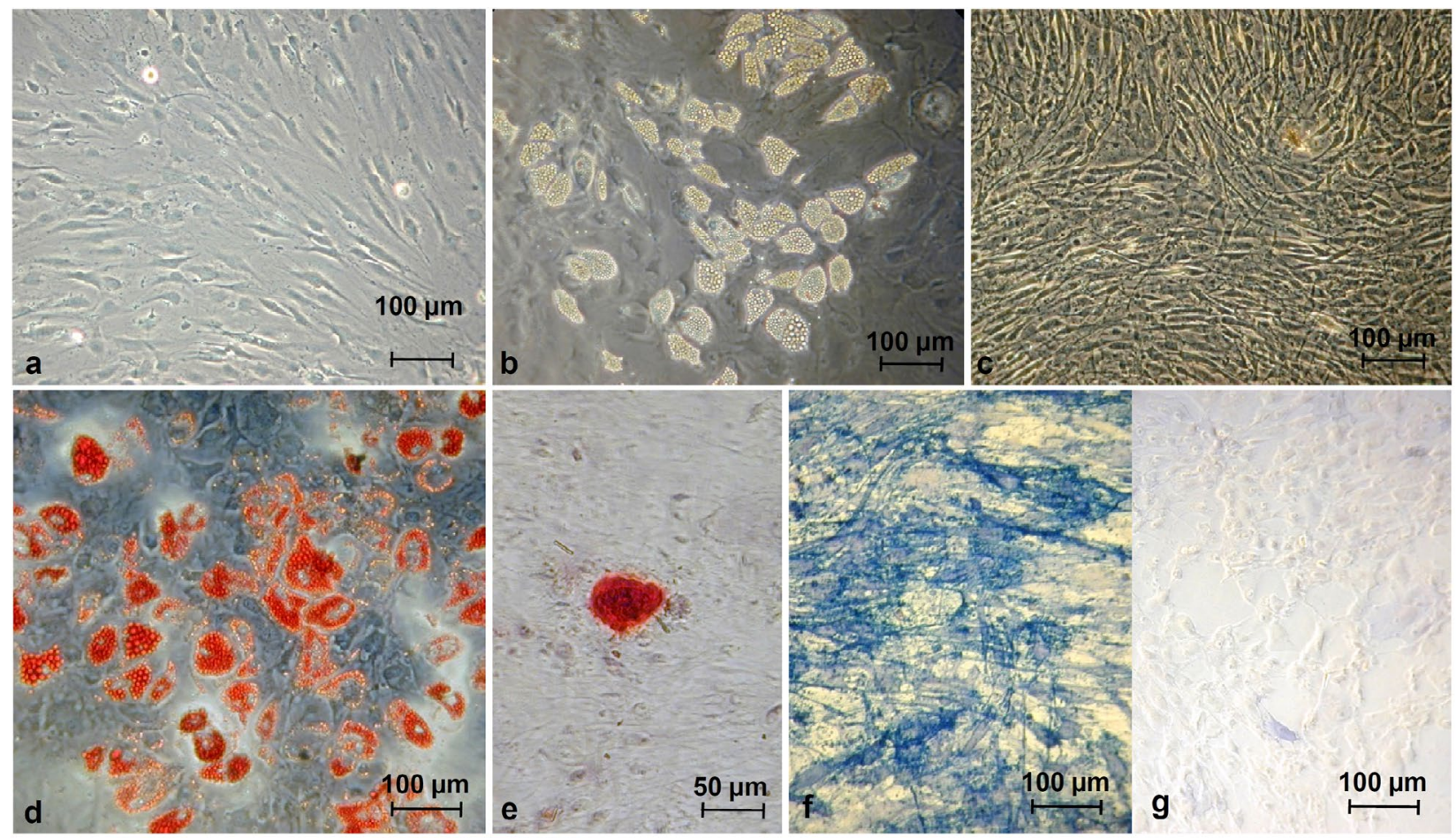

g

$100 \mu \mathrm{m}$

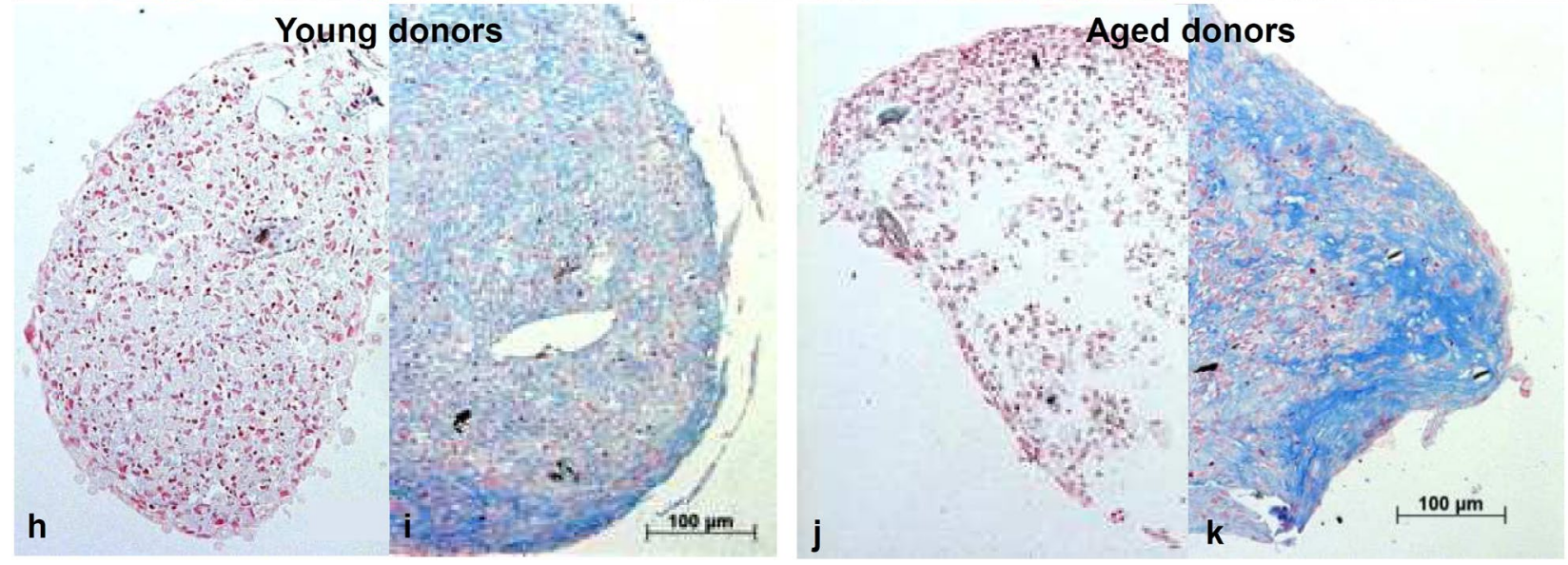

Fig. 4. Multipotent Differentiation (a-c) Phenotype of tenocyte-like cells after 3 weeks in (a) normal growth medium (control), (b) adipogenic differentiation medium, (c) osteogenic differentiation medium. (d) Adipogenic differentiated cells after Oil Red O staining with red stained lipid vacuoles, (e) Calcium accumulation after Alizarin Red S staining. (f) Blue ALP staining of osteogenic differentiated cells and (g) undifferentiated control cells. (h-k) Alcian Blue staining of chondrogenic differentiated tenocyte-like cell pellets of young (h-i) and aged (j-k) donors showed a positive staining compared to the undifferentiated control cells ( $h$ and $\mathbf{j}$ ).

The adipogenic differentiation potential of the cells was not significantly affected by age (Fig. $3 b$ ).

In terms of chondrogenic differentiation, no quantification could be performed. Only $n=1$ tenocyte-like cell culture for each group was used for the differentiation experiment. The Alcian Blue staining of the cell pellets revealed that cells of young and aged donors could be differentiated into a chondrogenic phenotype (Fig. 4 h-k).

\section{Stimulation potential}

\section{Cell activity}

The cell activity of young donors was significantly decreased after BMP-2 treatment at day 5 and 7, and only at day 7 in aged donors in the 2D-culture. For BMP-7 treatment, a significant dose-dependent increase of the cell activity was found for nearly all days and concentrations in the tenocyte-like cells of young and aged donors in 2D-culture. In cells of aged donors already the 3-day time point showed a significant increase (Fig. 5a and b).

The suppressing effect of BMP-2 within 2D-culture reversed in the low concentration group at day 7 , and was compensated in the $3 \mathrm{D}$-culture at all concentrations in tenocyte-like cells of young and aged donors. BMP7 led to significantly increased cell activity in the high concentration in both groups and additionally to an increase at low BMP-7 concentration at day 5 in the young donors group (Fig. 5c and d).

Direct comparison of young and aged donor cells revealed a significant increase of cell activity in the aged donor group following BMP-7 application (low dosed, day 3 , and 5, 2D-culture; and day 3 in 3D-culture). 

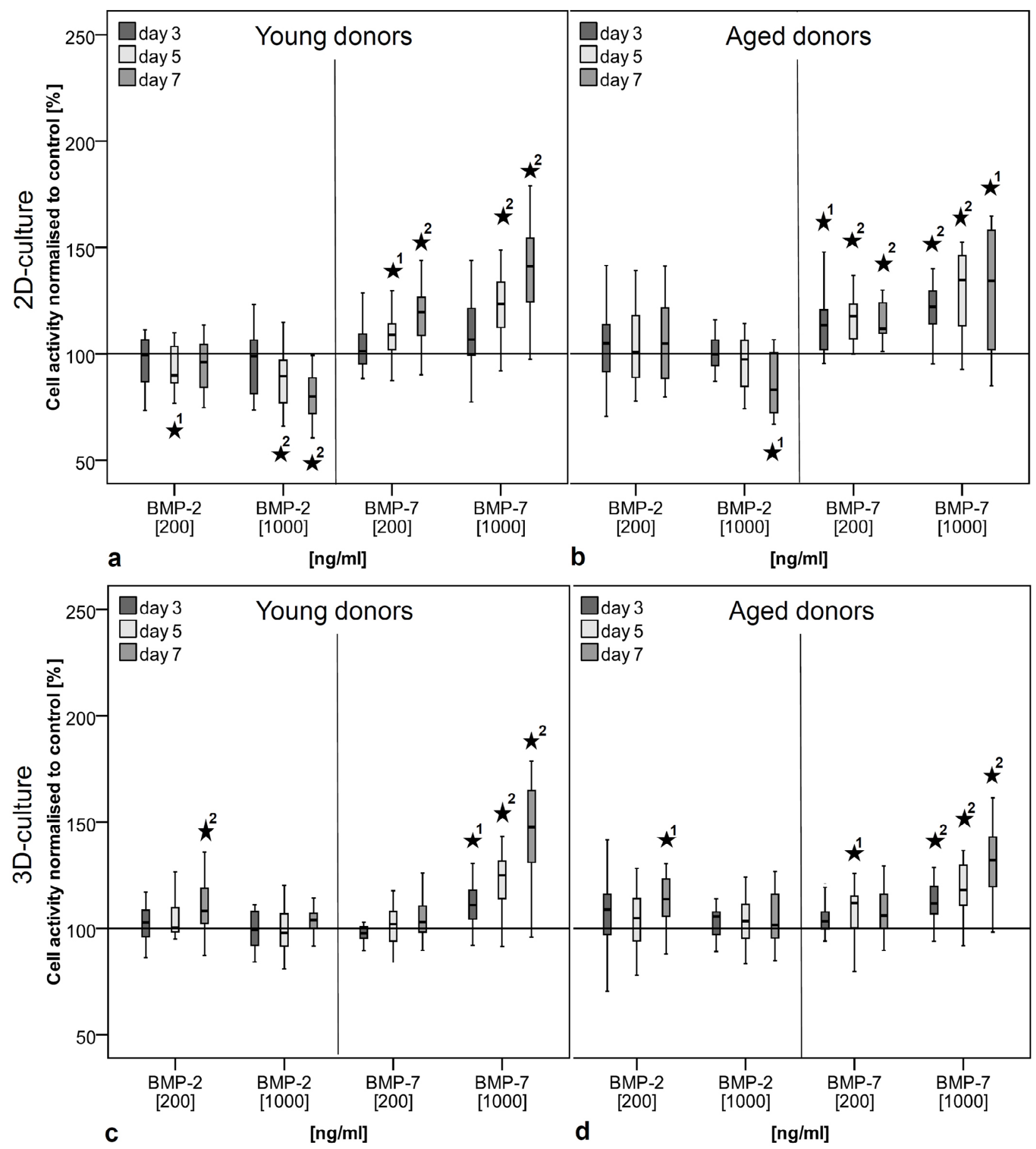

Fig. 5. Cell activity was measured by Alamar Blue assay and given as percentage of untreated control. Application of BMP-2 in 2D-culture of cells from young (a) and aged (b) donors significantly decreased activity compared to untreated control at low concentration at day 5, and at high concentration at days 5 and 7 (young donors), and at high concentration at day 7 (aged donors). BMP-7 significantly increased cell activity at nearly all concentrations and days in cells of young (a) and aged (b) donors. BMP-2 application in 3D-culture resulted in increased cell activity at day 7 at the low concentration in the cells of young $(\mathbf{c})$ and aged $(\mathbf{d})$ donors. Application of BMP-7 enhanced cell activity only at the high concentration. All significant differences from the untreated control are marked with an asterisk $(*)$. The numbers give details for the $p$-value: $1: p \leq 0.05 ; 2: p \leq 0.001$.

\section{Relative gene expression}

The Col-I expression of tenocyte-like cells in 2D-culture was increased by BMP-7 in both dosages in young and in the high dosage in the aged donor group. BMP-2 increased the Col-I expression only in the low concentration in the aged donor group. In 3D-culture, both growth factors significantly increased Col-I expression at nearly all concentrations, except for the low BMP-7 concentration in the aged donor group. Generally, BMP-7 treatment resulted in stronger effects compared to BMP-2, and the 3D-culture led to an enhancement of the results (Fig. 6).

The expression of Col-III was significantly increased in tenocytes of both donor groups by BMP-7 in the high concentration with both culturing conditions. A decreased 

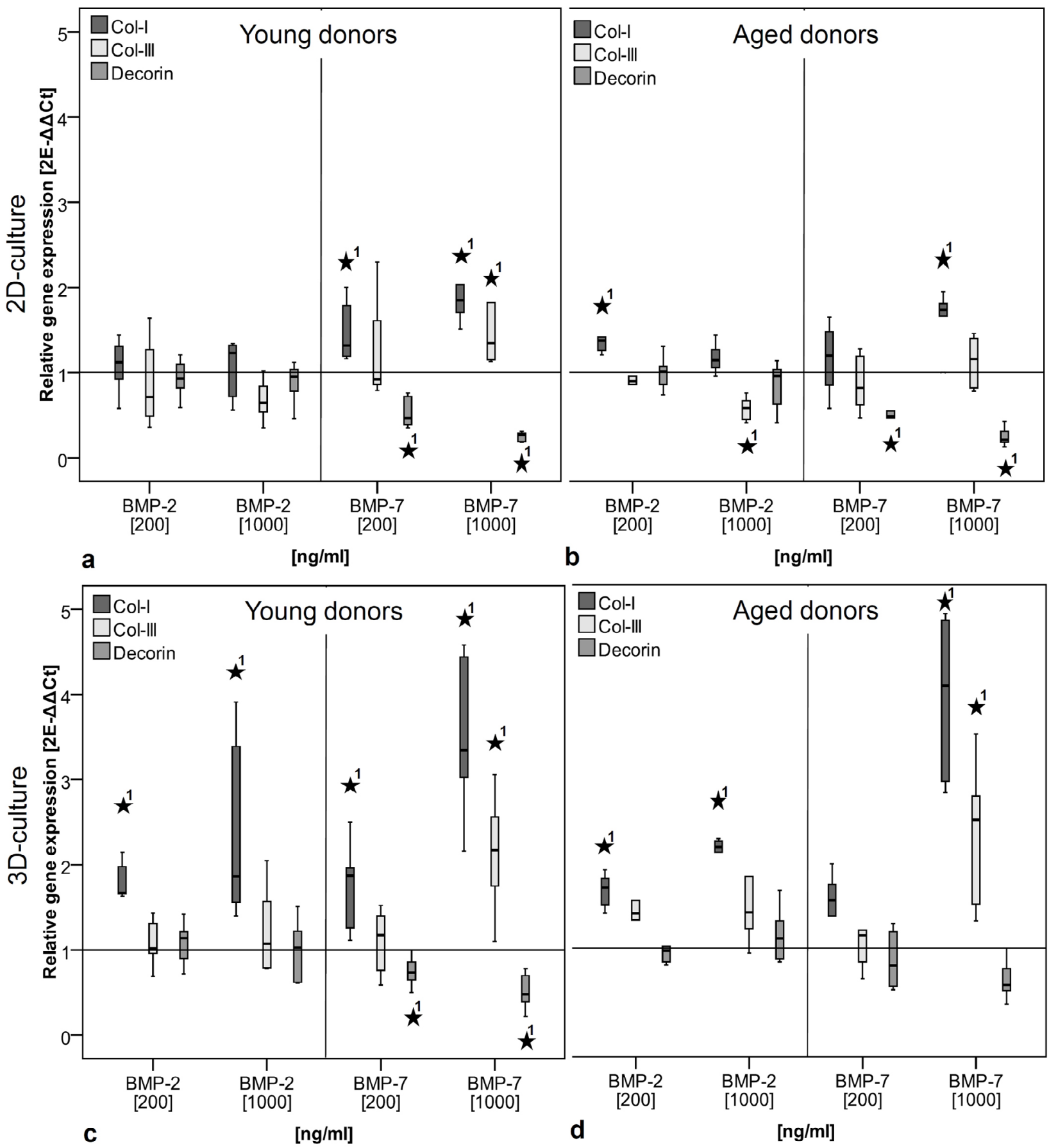

Fig. 6. Effect of growth factors on Col-I (dark gray bars), Col-III (light gray bars), and Decorin (grey bars) expression of tenocyte-like cells. (a) Marker expression of cells of young donors in 2D-culture was not significantly affected when treated with BMP-2. BMP-7 significantly increased Col-I expression in both and Col-III expression in high concentration, and decreased the Decorin expression. (b) Cells of aged donors in 2D-culture showed increased Col-I expression in low BMP-2 and high BMP-7 concentration. High BMP-2 concentration significantly decreased Col-III expression. Decorin expression was significantly decreased after BMP-7 treatment. (c) In 3D-culture of cells of young donors Col-I expression was significantly increased by BMP-2 and BMP-7 in all concentrations. Col-III expression was increased by high BMP-7 concentration, and Decorin was decreased by both BMP-7 concentrations, but not by BMP-2. (d) Cells of aged donors in 3D-culture showed significantly increased Col-I expression after BMP-2 application in both and BMP-7 in the high concentration. BMP-7 significantly increased Col-III expression in high concentration. The asterisks $(*)$ mark significant differences from the untreated control. The numbers give details for the $p$-value: $1: p \leq 0.05 ; 2: p \leq 0.001$.

Col-III expression was found for high BMP-2 treatment of the cells of aged donors in the 2D-culture (Fig. 6).

The expression of decorin, the most important proteoglycan in the tendon, was significantly decreased after application of BMP-7 dose-dependently, except the decrease was not significant in the aged donor group in 3D-culture. BMP-2 did not affect the decorin expression (Fig. 6). 

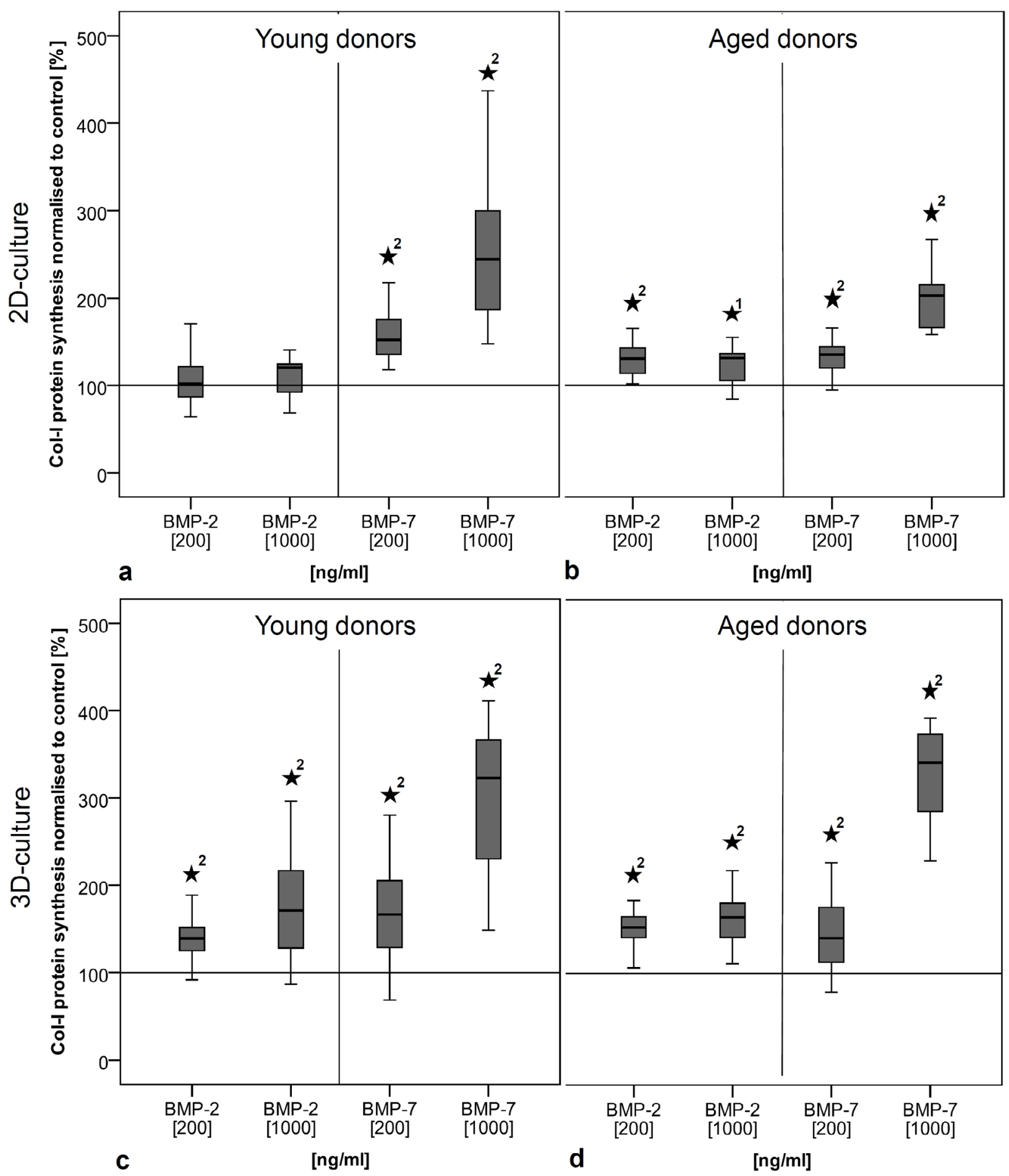

Fig. 7. Col-I protein synthesis in cell culture supernatant of day 7 after growth factor application. Col-I synthesis was calculated relative to total protein and given as percentage to untreated control. (a) Application of BMP-7 but not BMP-2 in 2D-culture of cells of young donors increased the Col-I protein synthesis significantly. (b) Col-I protein synthesis was significantly increased by both BMP-2 and BMP-7 concentrations in cells of aged donors in 2D-culture. (c and d) The BMP-2 and BMP-7 treatment in 3D-culture of tenocyte-like cells of young (c) and aged (d) donors significantly increased Col-I protein synthesis at all concentrations. The asterisks $(*)$ mark significant differences from the untreated control. The numbers give details for the $p$-value: $1: p \leq 0.05 ; 2: p \leq 0.001$.

The results for the expression of osteocalcin, as a marker for osteoblasts, and Col-II, as a marker for chondrocytes, did not suggest an osteogenic or chondrogenic differentiation of the tenocyte-like cells within the experimental period after BMP-2 or BMP-7 treatment (data not shown).

\section{Col-I protein synthesis}

In general, the Col-I protein synthesis was dosedependently increased after BMP-2 and BMP-7 application in 2D- and 3D-culture in tenocyte-like cells of young and aged donors. Only the BMP-2 treated cells of young donors 


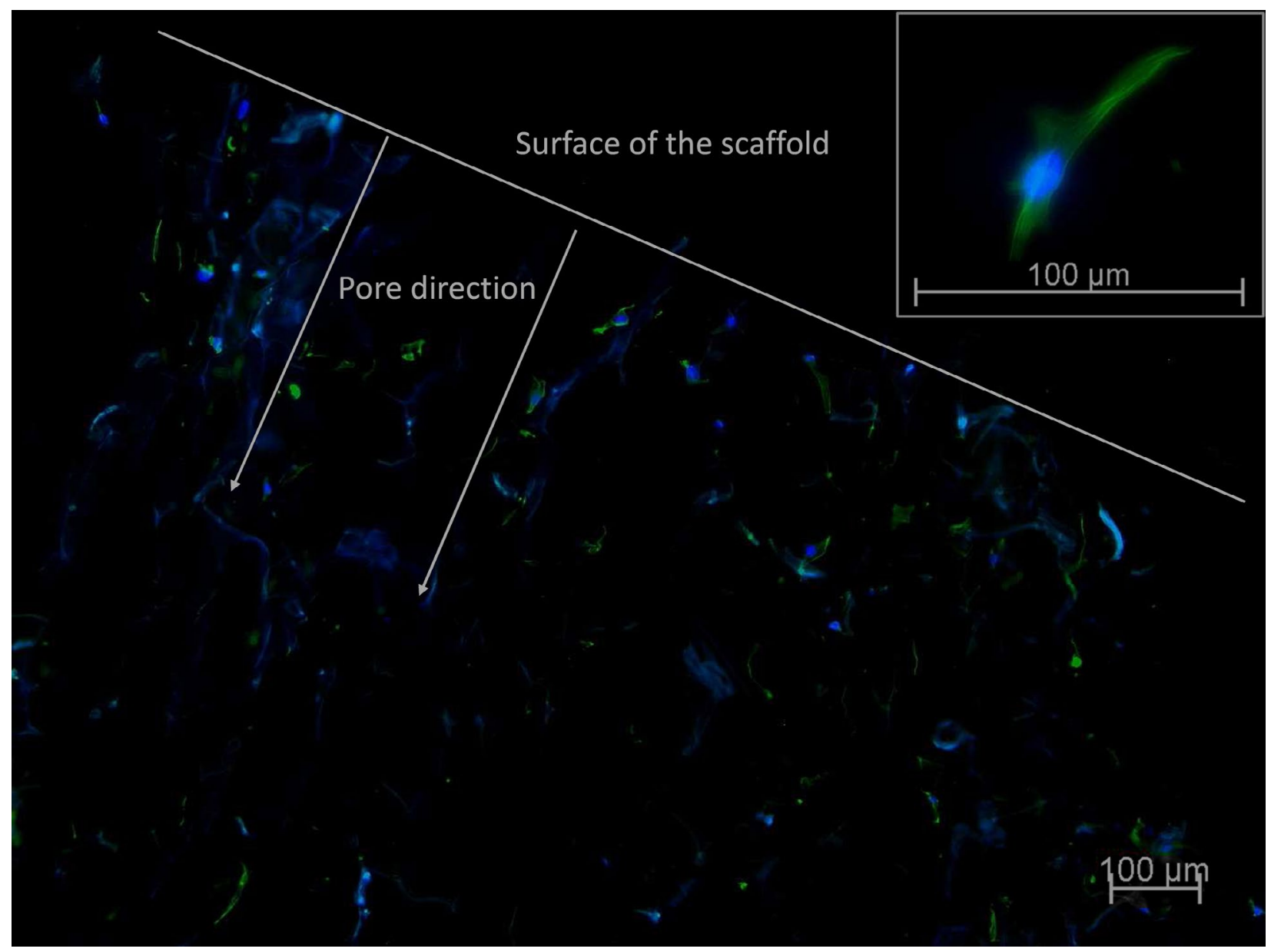

Fig. 8. Exemplary overview of tenocyte-like cells in Optimaix collagen scaffold after 7 days of stimulation with 1000 ng/mL BMP-7. Green staining represents Alexa Fluor Phalloidin stained actin filaments of tenocyte-like cells. Blue dots within the actin filaments are Dapi stained cell nuclei. The other blue parts show some autofluorescence of the scaffold.

in the 2D-culture revealed no significant differences when compared to the untreated control (Fig. 7).

In 2D-culture, the low dosed BMP-2 treatment increased Col-I protein synthesis in the aged donor group as compared to the cells of young donors. Contrary results were found for the low BMP-7 concentration group.

\section{Discussion}

In patients undergoing surgical rotator cuff repair, recurrent defects and non-healing are the primary postoperative complications. Clinical observations have indicated a correlation between increased retear rates and patient age (Boileau et al., 2005; Milgrom et al., 1995; Sorensen et al., 2007; Yamaguchi et al., 2006). To better understand this relationship, the present study has identified cell biological characteristics that might account for this correlation. Furthermore, the stimulation with growth factors such as BMP-2 and BMP-7 revealed no distinct age-dependent effects on tenocyte-like cells.

The results of the present study demonstrate that the cell biological characteristics of tenocyte-like cells differ depending on their donor characteristics. Cells from aged donors showed a decreased cell growth and stem cell potential in terms of their potential for self-renewal and osteogenic differentiation. These findings indicate a slower cell metabolism in cells of aged donors and might be a reason for a weaker tendon-bone healing of the rotator cuff. It was reported in the literature that additionally to the age of the donors and amongst other factors, the tear size can influence the characteristics of the tenocytes of the rotator cuff (Chaudhury and Carr, 2012). Microarray analysis for example revealed that the expression of Collagen 4, 12 and 14 were upregulated in small tears compared to massive tears and the expression of Aggrecan was upregulated in massive but not small tears compared to normal controls (Chaudhury et al., 2011). While keeping all clinical and radiological parameters equal between the young and the aged donors group, an influence of the respective parameters on the results of the study should be excluded.

Regarding the stimulation potential of the tenocyte-like cells, no clear age-related differences could be observed. Cells from both young and aged donors could be stimulated with BMP-2 and BMP-7, but more with BMP-7. This suggests that BMP-7 might have therapeutic potential to biologically enhance tendon-bone healing of the rotator cuff.

There have been very few studies investigating tendon cell cultures with respect to their age-dependent 
differences. In previous studies, foetal and adult cells from animal ligaments and tendons were compared, and it was shown that higher levels of Col-I and -III were present in foetal cells (Brink et al., 2006; Stalling and Nicoll, 2008). In the present study, no age-related differences were found with respect to Col-I protein synthesis, or the expression of Col-I and -III. This indicates that age-related changes are not seen at the level of the extracellular matrix in the present study.

Decorin is the most important proteoglycan in tendons, and it has been reported to enhance tissue regeneration while decreasing scar formation (Jarvinen and Ruoslahti, 2010). The anti-scarring activities of Decorin are caused by its inhibitory effects on TGF- $\beta$. TGF- $\beta 1$ is the main scar-inducing isoform, and TGF- $\beta 2$ augments the actions of TGF- $\beta 1$, whereas TGF- $\beta 3$ antagonises scar formation (Brunner and Blakytny, 2004; Bandyopadhyay et al., 2006; Ferguson et al., 2009). No significant differences in the expression of Decorin, TGF- $\beta 1$ and TGF- $\beta 3$ were found in the two groups of tenocyte-like cells. While the expression of TGF- $\beta 2$ was lower in aged donor cells, this change was not significant $(p=0.054)$. A higher expression of TGF- $\beta 2$ in aged donor cells might lead to increased scar formation in vivo, and may therefore translate into higher rates of recurrent defects.

Several in vitro studies have demonstrated that tendon cell cultures express stem cell markers and are able to both self-renewal and to undergo multipotent differentiation (Bi et al., 2007; de Mos et al., 2007; Zhang and Wang, 2010; Steinert et al., 2011). Our results are consistent with these previous findings, and additionally, it was shown that tenocyte-like cells of both young and aged donors have this stem cell potential. Cells from both groups fulfilled the minimal stem cell criteria (Dominici et al., 2006). However, in cells from aged donors, the stem cell potential was decreased with respect to their potential for self-renewal and osteogenic differentiation. This may be another reason for inferior tendon-bone healing in elderly patients. To the best of our knowledge, there have been no previous tendon cell culture studies, analysing the agerelated differences in stem cell potential. However, in a cell culture study with rat MSCs, no age-related changes were observed for stem cell phenotype (CD11b, CD29, CD31, CD44, CD45, CD81, CD90, CD105, CD172a), or osteogenic and adipogenic differentiation (Tokalov et al., 2007). Moreover, Stenderup et al. have reported that the bone forming capacity of human MSCs maintained in both young (24-27 years) and aged (71-81 years) donors (Stenderup et al., 2004). However, both studies lack a quantitative analysis and therefore cannot evaluate quantitative changes in the differentiation capacity of the cells, as it was done in the present study. Several in vitro studies using rat osteoprogenitors (Bellows et al., 2003), and human bone marrow cells (Oreffo et al., 1998a; Oreffo et al., 1998b; D'Ippolito et al., 1999; Stenderup et al., 2001) have demonstrated that the capacity for selfrenewal is not age-dependent. These contrasting findings may result from the use of different cell types (progenitor cells versus tenocyte-like cells) or different study design. Results consistent with the findings in this study were found by Oreffo et al., who reported that colony size is reduced in bone marrow cells of aged donors (Oreffo et al., 1998a; Oreffo et al., 1998b).

In a previous study, BMP-2 and BMP-7 was applied to tenocyte-like cells that had been pooled from rotator cuffs and biceps tendons, without distinguishing between young and aged patients (Pauly et al., 2011b). In the present study, only SSP tendons with a MRI classification of fatty muscle infiltration of grade 0 and 1 were biopsied. Also in contrast to this previous study, other concentrations of BMP-2 and -7 were used. Additionally, cells were stimulated with BMP-2 and -7 in 3D-culture, which represents a system closer to in vivo conditions (Stoll et al., 2010).

In general, tenocyte-like cells of young and aged donors showed a very robust response to BMP stimulation. As reported in the previous study, BMP-7 exposure exerts stronger effects than BMP-2 (Pauly et al., 2011b). While other groups have found no effect of BMP-2 on tenocyte cultures (Salingcarnboriboon et al., 2003; Thomopoulos et al., 2007), the previous findings that BMP-2 increased Col-I expression and protein synthesis were confirmed. This was observed in previous findings regarding BMP7, where once again, cell activity, Col-I expression and protein synthesis were strongly increased following BMP-7 application. These results are consistent with the findings of Tsai et al., Yamada et al. and Yeh et al., who have independently reported of significantly increased cell activity / proliferation and Col-I protein synthesis following BMP-7 stimulation in rat and bovine tendon cells of different origin (Tsai et al., 2003; Yamada et al., 2008; Yeh et al., 2008).

Various in vivo studies have reported on improved tendon-bone healing following application of BMP-2 and BMP-7 (Rodeo et al., 1999; Martinek et al., 2002; Mihelic et al., 2004; Higuera et al., 2005; Ma et al., 2007). In general, these studies have shown improved tendon-bone integration and higher biomechanical strength following ACL reconstructions or SSP tendon repair. The results from the present study suggested that such in vivo findings after BMP treatment may be explained by increased cell activity or Col-I expression and protein synthesis.

Decorin expression was decreased after BMP-7 treatment. Tendon healing of the rotator cuff often results in the formation of a biomechanically inferior scar tissue (Gerber et al., 1999; Rodeo, 2007). Decorin reduces scar formation, and may improve the biomechanical properties of tendons (Jarvinen and Ruoslahti, 2010). Thus, a reduced decorin expression after BMP-7 application may enhance scar formation, and therefore impair regeneration at the tendon bone insertion site. Further in vivo studies will be necessary to better understand this process.

Currently, the effects of BMP-2 and BMP-7 were analysed in 2D- and 3D-culture, with a more pronounced effect seen in 3D-cultures. The 3D-approach is a better model of the in vivo milieu, and it prevents tenocytes from redifferentiating or changing of phenotypes (SchulzeTanzil et al., 2004; Yao et al., 2006; Stoll et al., 2010). As demonstrated, the 3D-culture seems to be a better system for analysing the response of cells to growth factors. This has also been reported in a study using human skin fibroblasts after epidermal growth factor (EGF) treatment (Colige et al., 1990). However, the analysis of cell activity 
in 3D-culture by Alamar Blue assay was not as sensitive as it was in 2D-culture, because the red colour mainly formed inside the 3D-scaffold, and the transfer to the surrounding medium was limited. 2D-culture remains important to visualise cell morphology within the experimental period, a capability, which is hindered when using light microscopy in 3D-cultures. Moreover, as it has been shown that cells change morphology with increasing passages (Yao et al., 2006), cells at the earliest passage as possible were used, with passage 2 being the maximum.

Marginal significant differences between young and aged donor cells responded to BMP were observed. Increased cell activity (with $200 \mathrm{ng} / \mathrm{mL} \mathrm{BMP-7)}$ and Col-I protein synthesis (with $200 \mathrm{ng} / \mathrm{mL} \mathrm{BMP-2)}$ were found in the aged donor cells compared to the cells of young donors. In contrast, the Col-I protein synthesis was decreased after incubation with $200 \mathrm{ng} / \mathrm{mL} \mathrm{BMP-7}$ in cells of aged donors. The differences were significant between both groups, but did not follow a consistent pattern. These results suggest that the effect of BMP-2 and BMP-7 on cells of aged donors is comparable to those of young donors.

\section{Study limitations}

Due to limitations in obtaining tissue biopsies, the present data were extracted exclusively from cells harvested at the time of rotator cuff surgery, with no cells used from pre- or post-operative stages. Prospective clinical and radiographic (MRI) follow up over a period of at least 24 months are needed (and currently being compiled) to investigate a possible correlation with baseline biologic parameters. This would provide a holistic approach to assess for age-related differences in rotator cuff regeneration potential.

\section{Conclusions}

Age-related differences were found in the cell biological characteristics of the tenocyte-like cells, which may be one reason for varying healing rates following rotator cuff repair of patients from different age groups. It may follow that a reduced cell growth and stem cell potential, observed in vitro, correlates with a reduced number of tenocyte-like cells in vivo, and therefore may contribute to an inferior SSP tendon repair in elderly patients.

However, no distinct age-related differences were found in terms of cell response to BMP-2 or BMP-7. In other words, both young and aged male patients might benefit from BMP-2 or BMP-7 treatment. At the cellular level, our findings suggest that BMP-7 seems to be most promising for the treatment of rotator cuff tears to reduce rates of non-healing or recurrent defects following surgery.

The study might contribute to a more patient specific surgical repair of the rotator cuff instead of the current uniform therapy.

\section{Acknowledgements}

We thank the Deutsche Vereinigung für Schulter- und Ellenbogenchirurgie (DVSE) for the financial support of the study. A special thanks goes to Jelka Hartwig for the helpful support with the experiments within her internship. We would like to thank Dr. Martina Seifert (BCRT) for kindly providing us with the stem cell panel, including antibodies for analysing stem cell phenotype of the tenocyte-like cells. We furthermore would like to acknowledge the excellent assistance of the BCRT Flow Cytometry Lab. We thank Mario Thiele for writing the image analysing macro for analysing the number and average size of CFUs used in determining the potential for self-renewal. We furthermore would like to thank the BCRT cell harvesting core unit for kindly supporting the purchase of the SSP tendon material.

\section{References}

Aydin N, Kocaoglu B, Guven O (2010) Single-row versus double-row arthroscopic rotator cuff repair in small- to medium-sized tears. J Shoulder Elbow Surg 19: 722-725.

Bandyopadhyay B, Fan J, Guan S, Li Y, Chen M, Woodley DT, Li W (2006) A "traffic control" role for TGFbeta3: orchestrating dermal and epidermal cell motility during wound healing. J Cell Biol 172:1093-1105.

Bayne OBJ (1984) Long term results of surgical repair of full thickness rotator cuff tears. In: Surgery of the Shoulder (Bateman J, Welsh R, eds), Mosby, Philadelphia, pp 167-171.

Bellows CG, Pei W, Jia Y, Heersche JN (2003) Proliferation, differentiation and self-renewal of osteoprogenitors in vertebral cell populations from aged and young female rats. Mech Ageing Develop 124: 747757.

Bi Y, Ehirchiou D, Kilts TM, Inkson CA, Embree MC, Sonoyama W, Li L, Leet AI, Seo BM, Zhang L, Shi S, Young MF (2007) Identification of tendon stem/progenitor cells and the role of the extracellular matrix in their niche. Nat Med 13: 1219-1227.

Boileau P, Brassart N, Watkinson DJ, Carles M, Hatzidakis AM, Krishnan SG (2005) Arthroscopic repair of full-thickness tears of the supraspinatus: does the tendon really heal? J Bone Joint Surg.Am 87: 1229-1240.

Brink HE, Miller GJ, Beredjiklian PK, Nicoll SB (2006) Serum-dependent effects on adult and fetal tendon fibroblast migration and collagen expression. Wound Rep Regen 14: 179-186.

Brunner G, Blakytny R (2004) Extracellular regulation of TGF-beta activity in wound repair: growth factor latency as a sensor mechanism for injury. Thromb Haemost 92: 253-261.

Burks RT, Crim J, Brown N, Fink B, Greis PE (2009) A prospective randomized clinical trial comparing arthroscopic single- and double-row rotator cuff repair: magnetic resonance imaging and early clinical evaluation. Am J Sports Med 37: 674-682.

Chaudhury S, Carr AJ (2012) Lessons we can learn from gene expression patterns in rotator cuff tears and tendinopathies. J Shoulder Elbow Surg 21: 191-199.

Chaudhury S, Xia Z, Hulley P, Marchi E, Carr A (2011) Genetic profiling of changes underlying different sized human rotator cuff tendon tears. Trans ORS 2011 Ann Meet, abstr 0397. 
Cho NS, Lee BG, Rhee YG (2011) Arthroscopic rotator cuff repair using a suture bridge technique: is the repair integrity actually maintained? Am J Sports Med 39: 21082116.

Chung SW, Oh JH, Gong HS, Kim JY, Kim SH (2011) Factors affecting rotator cuff healing after arthroscopic repair: osteoporosis as one of the independent risk factors. Am J Sports Med 39: 2099-2107.

Colige A, Nusgens B, Lapiere CM (1990) Response to epidermal growth factor of skin fibroblasts from donors of varying age is modulated by the extracellular matrix. $\mathrm{J}$ Cell Physiol 145: 450-457.

D'Ippolito G, Schiller PC, Ricordi C, Roos BA, Howard GA (1999) Age-related osteogenic potential of mesenchymal stromal stem cells from human vertebral bone marrow. J Bone Miner Res 14: 1115-1122.

De Mos M, Koevoet WJ, Jahr H, Verstegen MM, Heijboer MP, Kops N, van Leeuwen JP, Weinans H, Verhaar JA, van Osch GJ (2007) Intrinsic differentiation potential of adolescent human tendon tissue: an in vitro cell differentiation study. BMC Musculoskel Dis 8: 16.

Deutsch A, Kroll DG, Hasapes J, Staewen RS, Pham C, Tait C (2008) Repair integrity and clinical outcome after arthroscopic rotator cuff repair using single-row anchor fixation: a prospective study of single-tendon and twotendon tears. J Shoulder Elbow Surg 17: 845-852.

Dominici M, Le Blanc K, Mueller I, Slaper-Cortenbach I, Marini F, Krause D, Deans R, Keating A, Prockop Dj, Horwitz E (2006) Minimal criteria for defining multipotent mesenchymal stromal cells. The International Society for Cellular Therapy position statement. Cytotherapy 8: 315 317.

Ferguson MW, Duncan J, Bond J, Bond J, Bush J, Durani P, So K, Taylor L, Chantrey J, Mason T, James G, Laverty H, Occleston NL, Sattar A, Ludlow A, O'Kane S (2009) Prophylactic administration of avotermin for improvement of skin scarring: three double-blind, placebocontrolled, phase I/II studies. Lancet 373: 1264-1274.

Frank JB, ElAttrache NS, Dines JS, Blackburn A, Crues J, Tibone JE (2008) Repair site integrity after arthroscopic transosseous-equivalent suture-bridge rotator cuff repair. Am J Sports Med 36: 1496-1503.

Fuchs B, Weishaupt D, Zanetti M, Hodler J, Gerber C (1999) Fatty degeneration of the muscles of the rotator cuff: assessment by computed tomography versus magnetic resonance imaging. J Shoulder Elbow Surg 8: 599-605.

Gerber C, Schneeberger AG, Perren SM, Nyffeler RW (1999) Experimental rotator cuff repair. A preliminary study. J Bone Joint Surg.Am 81: 1281-1290.

Gladstone JN, Bishop JY, Lo IK, Flatow EL (2007) Fatty infiltration and atrophy of the rotator cuff do not improve after rotator cuff repair and correlate with poor functional outcome. Am J Sports Med 35: 719-728.

Goutallier D, Postel JM, Bernageau J, Lavau L, Voisin MC (1994) Fatty muscle degeneration in cuff ruptures. Pre- and postoperative evaluation by CT scan. Clin Orthop Rel Res 304:78-83.

Goutallier D, Postel JM, Gleyze P, Leguilloux P, Van Driessche S (2003) Influence of cuff muscle fatty degeneration on anatomic and functional outcomes after simple suture of full-thickness tears. J Shoulder Elbow Surg 12: 550-554.

Grasso A, Milano G, Salvatore M, Falcone G, Deriu L, Fabbriciani C (2009) Single-row versus double-row arthroscopic rotator cuff repair: a prospective randomized clinical study. Arthroscopy 25: 4-12.

Higuera CA, Inoue N, Lim JS, Zhang E, Dimaano N, Frassica FJ, Chao (2005) Tendon reattachment to a metallic implant using an allogenic bone plate augmented with rhOP-1 vs. autogenous cancellous bone and marrow in a canine model. J Orthop Res 23: 1091-1099.

Hsu C, Chang J (2004) Clinical implications of growth factors in flexor tendon wound healing. J Hand Surg 29: 551-563.

Jarvinen TA, Ruoslahti E (2010) Target-seeking antifibrotic compound enhances wound healing and suppresses scar formation in mice. Proc Natl Acad Sci USA 107: 21671-21676.

Livak KJ, Schmittgen TD (2001) Analysis of relative gene expression data using real-time quantitative PCR and the 2(-delta delta C(T)) method. Methods 25:402-408.

Ma CB, Kawamura S, Deng XH, Ying L, Schneidkraut J, Hays P, Rodeo SA (2007) Bone morphogenetic proteinssignaling plays a role in tendon-to-bone healing: a study of rhBMP-2 and noggin. Am J Sports Med 35: 597-604.

Maffulli N, Moller HD, Evans CH (2002) Tendon healing: can it be optimised? Br J Sports Med 36: 315-316.

Martinek V, Latterman C, Usas A, Abramowitch S, Woo SL, Fu FH, Huard J 2002) Enhancement of tendon-bone integration of anterior cruciate ligament grafts with bone morphogenetic protein-2 gene transfer: a histological and biomechanical study. J Bone Joint Surg Am 84-A: 11231131.

Mihelic R, Pecina M, Jelic M, Zoricic S, Kusec V, Simic P, Bobinac D, Lah B, Legovic D, Vukicevic S (2004) Bone morphogenetic protein-7 (osteogenic protein-1) promotes tendon graft integration in anterior cruciate ligament reconstruction in sheep. Am J Sports Med 32: 1619-1625.

Milgrom C, Schaffler M, Gilbert S, van Holsbeeck M (1995) Rotator-cuff changes in asymptomatic adults. The effect of age, hand dominance and gender. J Bone Joint Surg Br 77: 296-298.

Oreffo RO, Bennett A, Carr AJ, Triffitt JT (1998a) Patients with primary osteoarthritis show no change with ageing in the number of osteogenic precursors. Scand J Rheumatol 27: 415-424.

Oreffo RO, Bord S, Triffitt JT (1998b) Skeletal progenitor cells and ageing human populations. Clin Sci (Lond) 94: 549-555.

Patte D (1990) Classification of rotator cuff lesions. Clin Orthopaed Rel Res:81-86.

Pauly S, Fiebig D, Kieser B, Albrecht B, Schill A, Scheibel M (2011a) Biomechanical comparison of four double-row speed-bridging rotator cuff repair techniques with or without medial or lateral row enhancement. Knee Surg Sports Traumatol Arthrosc 19: 2090-2097.

Pauly S, Kieser B, Schill A, Gerhardt C, Scheibel M (2010a) Biomechanical comparison of 4 double-row suture-bridging rotator cuff repair techniques using different medial-row configurations. Arthroscopy 26: 1281-1288. 
Pauly S, Klatte F, Strobel C, Schmidmaier G, Greiner S, Scheibel M, Wildemann B (2010b) Characterization of tendon cell cultures of the human rotator cuff. Eur Cell Mater 20: 84-97.

Pauly S, Klatte F, Strobel C, Schmidmaier G, Greiner S, Scheibel M, Wildemann B (2011b) BMP-2 and BMP-7 affect human rotator cuff tendon cells in vitro. J Shoulder Elbow Surg 21:464-73.

Pittenger MF, Mackay AM, Beck SC, Jaiswal RK, Douglas R, Mosca JD, Moorman MA, Simonetti DW, Craig S, Marshak DR (1999) Multilineage potential of adult human mesenchymal stem cells. Science 284:143-147.

Rodeo SA (2007) Biologic augmentation of rotator cuff tendon repair. J Shoulder Elbow Surg 16: S191-197.

Rodeo SA, Potter HG, Kawamura S, Turner AS, Kim HJ, Atkinson BL (2007) Biologic augmentation of rotator cuff tendon-healing with use of a mixture of osteoinductive growth factors. J Bone Joint Surg Am 89:2485-2497.

Rodeo SA, Suzuki K, Deng XH, Wozney J, Warren RF (1999) Use of recombinant human bone morphogenetic protein-2 to enhance tendon healing in a bone tunnel. Am J Sports Med 27: 476-488.

Salingcarnboriboon R, Yoshitake H, Tsuji K, Obinata M, Amagasa T, Nifuji A, Noda M.(2003) Establishment of tendon-derived cell lines exhibiting pluripotent mesenchymal stem cell-like property. Exp Cell Res 287: 289-300.

Schulze-Tanzil G, Mobasheri A, Clegg PD, Sendzik J, John T, Shakibaei M (2004) Cultivation of human tenocytes in high-density culture. Histochem Cell Biol 122: 219-228.

Shen PH, Lien SB, Shen HC, Lee CH, Wu SS, Lin LC (2008) Long-term functional outcomes after repair of rotator cuff tears correlated with atrophy of the supraspinatus muscles on magnetic resonance images. J Shoulder Elbow Surg 17: 1S-7S.

Sorensen AK, Bak K, Krarup AL, Thune CH, Nygaard M, Jørgensen U, Sloth C, Torp-Pedersen S. (2007) Acute rotator cuff tear: do we miss the early diagnosis? A prospective study showing a high incidence of rotator cuff tears after shoulder trauma. J Shoulder Elbow Surg 16: 174-180.

Stalling SS, Nicoll SB (2008) Fetal ACL fibroblasts exhibit enhanced cellular properties compared with adults. Clin Orthop Rel Res 466: 3130-3137.

Steinert AF, Kunz M, Prager P, Barthel T, Jakob F, Nöth U, Murray MM, Evans CH, Porter RM (2011) Mesenchymal stem cell characteristics of human anterior cruciate ligament outgrowth cells. Tissue Eng A 17: 1375 1388.

Stenderup K, Justesen J, Eriksen EF, Rattan SI, Kassem M (2001) Number and proliferative capacity of osteogenic stem cells are maintained during aging and in patients with osteoporosis. J Bone Miner Res 16: 1120-1129.

Stenderup K, Rosada C, Justesen J, Al-Soubky T, Dagnaes-Hansen F, Kassem M (2004) Aged human bone marrow stromal cells maintaining bone forming capacity in vivo evaluated using an improved method of visualization. Biogerontology 5: 107-118.

Stoll C, John T, Endres M, Rosen C, Kaps C, Kohl B, Sittinger M, Ertel W, Schulze-Tanzil G (2010) Extracellular matrix expression of human tenocytes in three-dimensional air-liquid and PLGA cultures compared with tendon tissue: implications for tendon tissue engineering. J Orthop Res 28: $1170-1177$.

Tashjian RZ, Hollins AM, Kim HM, Teefey SA, Middleton WD, Steger-May K, Galatz LM, Yamaguchi K (2010) Factors affecting healing rates after arthroscopic double-row rotator cuff repair. Am J Sports Med 38: 2435 2442.

Thomopoulos S, Harwood FL, Silva MJ, Amiel D, Gelberman RH (2005) Effect of several growth factors on canine flexor tendon fibroblast proliferation and collagen synthesis in vitro. J Hand Surg 30: 441-447.

Thomopoulos S, Zaegel M, Das R, Harwood FL, Silva MJ, Amiel D, Sakiyama-Elbert S, Gelberman RH (2007) PDGF-BB released in tendon repair using a novel delivery system promotes cell proliferation and collagen remodeling. J Orthop Res 25: 1358-1368.

Tokalov SV, Gruener S, Schindler S, Iagunov AS, Baumann M, Abolmaali ND (2007) A number of bone marrow mesenchymal stem cells but neither phenotype nor differentiation capacities changes with age of rats. Mol Cell 24: 255-260.

Tsai AD, Yeh LC, Lee JC (2003) Effects of osteogenic protein-1 (OP-1, BMP-7) on gene expression in cultured medial collateral ligament cells. J Cell Biochem 90: 777791.

Yamada M, Akeda K, Asanuma K, Thonar EJ, An HS, Uchida A, Masuda K (2008) Effect of osteogenic protein-1 on the matrix metabolism of bovine tendon cells. J Orthop Res 26: 42-48.

Yamaguchi K, Ditsios K, Middleton WD, Hildebolt CF, Galatz LM, Teefey SA (2006) The demographic and morphological features of rotator cuff disease. A comparison of asymptomatic and symptomatic shoulders. J Bone Joint Surg.Am 88: 1699-1704.

Yao L, Bestwick CS, Bestwick LA, Maffulli N, Aspden RM (2006) Phenotypic drift in human tenocyte culture. Tissue Eng 12: 1843-1849.

Yeh LC, Tsai AD, Lee JC (2008) Bone morphogenetic protein-7 regulates differentially the mRNA expression of bone morphogenetic proteins and their receptors in rat achilles and patellar tendon cell cultures. J Cell Biochem 104: 2107-2122.

Zhang J, Wang JH (2010) Characterization of differential properties of rabbit tendon stem cells and tenocytes. BMC Musculoskel Dis 11: 10.

\section{Discussion with Reviewers}

Reviewer I: Please justify the 1-day sampling point rather than longitudinal analysis!

Authors: We did a longitudinal analysis of the cell growth for the cell biological characteristics and cell activity for the stimulation potential, because it is a non-toxic method for the cells and can be used at different time points within a culture. For the RNA isolation and Real-Time PCR for each time point additional tenocytes would be needed, which would have required much more primary tenocytes. The amount of cells at early passages for each patient, however, is very limited. We therefore decided to use only the cell 
growth/cell activity analysis as longitudinal parameter and the others as endpoint parameters. However, we analysed the Col-I synthesis from cell culture supernatant at day 4 and 7 additionally to the 14-day time point.

Reviewer II: Why were the cells fixed with formalin before the staining? The reaction here is based on the enzymatic activity of the ALP, which might be reduced by fixation! Authors: As stated in the literature the fixation of cells prior to ALP staining is a common procedure (Abukawa et al., 2009, additional reference), and is also recommended for commercial kits from for example Sigma-Aldrich. The fixation of the cells should avoid detachment of the cells from the bottom within the incubation time.

Reviewer II: Were there signs of hypoxia in the 3D scaffold?

Authors: Unfortunately, we cannot provide a satisfactory answer to that question, since we did not analyse any hypoxic effect like apoptosis in the scaffolds. The scaffolds are relatively small, have a macroporous structure and cells were seeded at a low density. Furthermore, the cell activity of the tenocytes in the scaffolds was good over the entire culture period. In the sections we stained as examples, the macroscopic images revealed good cell morphology even in the middle of the scaffold. We therefore assume that no hypoxia takes place in the scaffolds. Additionally to that another group working with these scaffolds seeded larger scaffolds (diameter $13 \mathrm{~mm}$ versus $6 \mathrm{~mm}$ ) with a much higher cell density $\left(7.5 \times 10^{3} / \mu \mathrm{L}\right.$ versus $\left.2.35 \times 10^{2} / \mu \mathrm{L}\right)$ and morphological analysis of the cells in the scaffolds revealed an overall viable phenotype (Petersen et al., 2012, additional reference).

Reviewer II: The authors showed the stem cell-like phenotype as well as the ability of cells to differentiate towards osteoblasts in response to dexamethasone. Furthermore the cells respond to BMP by upregulating Col $\mathrm{I}$, indicating that the receptors are present. Nevertheless, in stimulation experiments with BMP no osteoblast differentiation was observed. Can the authors give an explanation or speculation about the mechanism involved in the suppression?

Authors: We agree that BMP-2 and BMP-7 can facilitate ectopic bone formation in vivo and promote and regulate osteoblastic differentiation of various cell types in vitro. We speculate that a 7-day BMP stimulation is a too short a time frame to see a direct effect on the osteoblastic differentiation evaluated by osteocalcin expression of the tenocytes. Most differentiation studies for BMP-2 and -7 last about 2-3 weeks before analysis of the respective markers (Shen et al., 2010; Steinert et al., 2011; Luong et al., 2012). We assume that the BMP stimulation at first led to an induced proliferation and matrix production (Col-I and -II) of the tenocytes and that differentiation takes place later on when cells are more than $100 \%$ confluent. Furthermore, in the literature additional factors like L-ascorbic acid, $\beta$-glycerophosphate or dexamethasone are added to the cell cultures (Asahina et al., 1996, additional reference; Bi et al., 2005; Steinert et al., 2011, text references), which may additionally influence the differentiation capacity. We speculate further, that since only a portion of the tenocyte-like cells in our study seem to have a stem cell potential, the potential for osteogenic differentiation after stimulation with the BMPs may be slower or weaker compared to the stem cell approaches found in the literature (Luu et al., 2007; Shen et al., 2010).

\section{Additional References}

Abukawa H, Phelps M, Jackson P, Smith RM, Vacanti JP, Kaban LB, Troulis MJ (2009) Effect of ibuprofen on osteoblast differentiation of porcine bone marrow-derived progenitor cells. J Oral Maxillofac Surg 67: 2412-2417.

Asahina I, Sampath TK, Hauschka PV (1996) Human osteogenic protein-1 induces chondroblastic, osteoblastic, and/or adipocytic differentiation of clonal murine target cells. Exp Cell Res 222: 38-47.

Luong LN, Ramaswamy J, Kohn DH (2012) Effects of osteogenic growth factors on bone marrow stromal cell differentiation in a mineral-based delivery system. Biomaterials 33: 283-294.

Luu HH, Song WX, Luo X, Manning D, Luo J, Deng ZL, Sharff KA, Montag AG, Haydon RC, He TC (2007) Distinct roles of bone morphogenetic proteins in osteogenic differentiation of mesenchymal stem cells. J Orthop Res 25: 665-677.

Petersen A, Joly P, Bergmann C, Korus G, Duda G (2012) The impact of substrate stiffness and mechanical loading on fibroblast-induced scaffold remodeling. Tissue Eng A, in press.

Shen B, Wei A, Whittaker S, Williams LA, Tao H, Ma DD, Diwan AD (2010) The role of BMP-7 in chondrogenic and osteogenic differentiation of human bone marrow multipotent mesenchymal stromal cells in vitro. J Cell Biochem 109: 406-416. 